\title{
PENGARUH KEMAMPUAN PEMAHAMAN KONSEP, KEMAMPUAN KOMUNIKASI DAN KONEKSI TERHADAP KEMAMPUAN PEMECAHAN MASALAH
}

\author{
Sri Hartati ${ }^{1}$, Ilham Abdullah dan Saleh Haji ${ }^{2}$ \\ ${ }^{1}$ Mahasiswa dan ${ }^{2}$ Dosen Program Studi Pascasarjana (S2) Pendidikan \\ Matematika FKIP UNIB \\ E-mail: srihartati909@yahoo.co.id
}

\begin{abstract}
ABSTRAK
Penelitian ini bertujuan untuk mengetahui pengaruh kemampuan pemamahan konsep $\left(\mathrm{X}_{1}\right)$, kemampuan komunikasi $\left(\mathrm{X}_{2}\right)$ dan kemampuan koneksi matematika $\left(\mathrm{X}_{3}\right)$ terhadap kemampuan pemecahan masalah $(\mathrm{Y})$; pengaruh kemampuan pemahaman konsep $\left(\mathrm{X}_{1}\right)$ terhadap kemampuan komunikasi $\left(\mathrm{X}_{2}\right)$, pengaruh kemampuan pemahaman konsep $\left(\mathrm{X}_{1}\right)$ terhadap kemampuan koneksi $\left(\mathrm{X}_{3}\right)$ dan pengaruh kemampuan komunikasi $\left(\mathrm{X}_{2}\right)$ terhadap kemampuan koneksi $\left(\mathrm{X}_{3}\right)$. Jenis penelitian ini adalah penelitian survei dengan pendekatan kuantitatif. Populasinya adalah siswa Kelas VII SMP Negeri 1 Padang Jaya. Pengambilan sampel dilakukan menggunakan teknik non-probability sampling, jenis sampel adalah sampel jenuh. Instrumen tes menggunakan Skala Likert dan uraian digunakan untuk pengambilan data. Data dianalisis dengan teknik Analisis Jalur dengan taraf signifikasi 5\%. Hasil penelitian menunjukkan (1) ada pengaruh kemampuan pemahaman konsep $(\rho \mathrm{yx} 1 \mathrm{X} 1=0,374)$, kemampuan komunikasi $(\rho \mathrm{yx} 2 \mathrm{X} 2=0,181)$, kemampuan koneksi $((\rho \mathrm{yx} 3 \mathrm{X} 3=$ $0,201)$ terhadap kemampuan pemecahan masalah; (2) pengaruh kemampuan pemahaman konsep $(\rho \times 2 \times 1 \times 1=0,323)$ terhadap kemampuan komunikasi; (3) kemampuan pemahaman konsep $(\rho \times 3 \times 1 \times 3=0,442)$ terhadap kemampuan koneksi, serta pengaruh kemampuan komunikasi $(\rho \times 3 \times 2 \times 3=0,470)$ terhadap kemampuan koneksi.
\end{abstract}

Kata kunci: kemampuan komunikasi, kemampuan koneksi matematika, kemampuan pemahaman konsep, kemampuan pemecahan masalah.

\begin{abstract}
This research aims to determine the influence of concept understanding ability $\left(X_{1}\right)$, communication ability $\left(X_{2}\right)$ and mathematical connection ability $\left(X_{3}\right)$ on problems solving ability $(Y)$; the influence of concept understanding ability $\left(X_{1}\right)$ on communication ability $\left(X_{2}\right)$; the influence of concept understanding ability $\left(X_{1}\right)$ on mathematical connection ability $\left(X_{3}\right)$ and communication ability $\left(X_{2}\right)$ on connection ability $\left(X_{3}\right)$. This research is a survey research with quantitative approach. Population of the research is the second grade students of Public Junior High School 1 of Padang Jaya. The taking of samples use non-probability sampling method. Type of sampling is saturated samples. The taking of data uses Likert Scale and description as the test instruments. Method of data analysis uses Path Analysis with significance level 5\%. Results of the research shows that (1) concept understanding ability ( $\rho y x 1 X 1=0,374)$, communication ability $(\rho y x 2 X 2=0,181$ and connection ability ( $\rho y x 3 \times 3=0,201)$ influence on problems solving ability; (2) the influence of concept understanding ability $(\rho \times 2 \times 1 \times 1=0,323)$ on communication ability; (3) concept understanding ability $(\rho \times 3 \times 1 \times 3=0,442)$ influences on connection ability and (4) communication ability $(\rho \times 3 \times 2 \times 3=0,470)$ influences connection ability.
\end{abstract}

Keywords: $\quad$ ability of concept understanding, ability of communication, ability of mathematical connection, ability of problems solving 


\section{PENDAHULUAN}

Pemecahan masalah matematika tergolong penting, namun di sisi lain, siswa sering mengalami kesulitan dalam pemecahan masalah matematika. Kelemahan dan kesulitan siswa dalam menjawab soal pemecahan masalah disebabkan oleh rendahnya penguasaan matematika, seperti konsep matematika.

Pemahaman konsep merupakan landasan sangat penting, karena dengan penguasaan konsep akan memudahkan siswa dalam mempelajari matematika. Dengan penguasaan konsep yang baik, siswa memiliki bekal dasar yang baik pula untuk mencapai kemampuan dasar yang lain, seperti penalaran, komunikasi, koneksi dan pemecahan masalah. Hal ini senada dengan yang dikemukakan oleh Rony Hariyadi (2012), manfaat dari konsep merupakan dasar untuk mental yang lebih tinggi, konsep sangat diperlukan untuk pemecahan masalah (problems solving).

Kemampuan pemahaman konsep menurut Asikin (dalam Edy Izwanto, 2012: 5) adalah memahami sesuatu kemampuan mengerti, mengubah informasi ke dalam bentuk yang bermakna. Kemampuan pemahaman konsep merupakan kemampuan untuk memahami ide-ide matematika yang menyeluruh dan fungsional. Kemampuan pemahaman konsep akan mempengaruhi kemampuan pemecahan masalah. Hal ini sejalan dengan hasil penelitian Sya'roni (2010) menunjukkan bahwa 46,40\% variasi skor kemampuan pemecahan masalah dipengaruhi oleh kemampuan pemahaman konsep.

Selain pemahaman konsep, kemampuan lain yang harus dimiliki siswa untuk menunjang keberhasilannya dalam pemecahan masalah diperlukan kemampuan komunikasi. Komunikasi matematika dapat diartikan sebagai suatu kemampuan siswa dalam menyampaikan sesuatu yang diketahuinya baik secara lisan maupun tulisan, baik dengan media maupun tanpa media. Dengan kemampuan komunikasi yang baik, maka suatu masalah akan lebih cepat bisa direpresentasikan dengan benar dan hal ini akan mendukung untuk penyelesaian masalah. Kemampuan komunikasi matematis merupakan syarat untuk memecahkan masalah, artinya jika siswa tidak dapat berkomunikasi dengan baik memaknai permasalahan maupun konsep matematika, maka ia tidak dapat menyelesaikan masalah tersebut dengan baik. Hal ini sesuai dengan hasil penelitian Syahroni 
(2010), dimana 37,60\% variasi skor kemampuan pemecahan masalah ditentukan oleh kemampuan penalaran dan komunikasi melalui fungsi taksiran.

Kemampuan koneksi juga mempengaruhi kemampuan pemecahan masalah. Kemampuan koneksi matematika merupakan kemampuan mendasar yang harus dimiliki oleh siswa. Pentingnya kemampuan koneksi matematika terkandung dalam tujuan pembelajaran matematika seperti yang terdapat dalam Kurikulum Satuan Tingkat Pendidikan (KTSP) 2006, yaitu memahami konsep matematika, menjelaskan keterkaitan antar konsep dan mengaplikasikan konsep atau algoritma secara luwes, akurat, efesien dan tepat dalam pemecahan masalah.

Melalui koneksi matematika siswa diajarkan keterampilan dan konsep dalam memecahkan masalah dari berbagai bidang yang relevan, baik dengan matematika itu sendiri maupun dengan bidang diluar matematika. Hasil penelitian Pertiwi, Rina (2012) menunjukkan ada pengaruh yang signifikan antara kemampuan koneksi terhadap hasil belajar matematika.

Berbagai hasil penelitian tersebut di atas menunjukkan bahwa kemampuan komunikasi dan kemampuan koneksi berpengaruh positif terhadap kemampuan pemecahan masalah. Namun, pengaruh kemampuan pemahaman konsep, kemampuan komunikasi, kemampuan koneksi secara bersama-sama terhadap kemampuan pemecahan masalah belum diketahui. Pengaruh ini sangat penting untuk diketahui dalam rangka memaksimalkan upaya guru dalam rangka memaksimalkan kemampuan pemahaman konsep, kemampuan komunikasi dan kemampuan koneksi dalam upaya meningkatkan kemampuan pemecahan masalah.

Berdasarkan uraian latar belakang di atas, maka yang menjadi rumusan masalah dalam penelitian ini adalah, yaitu (1) apakah kemampuan pemahaman konsep berpengaruh terhadap kemampuan pemecahan masalah?; (2) apakah kemampuan komunikasi berpengaruh terhadap kemampuan pemecahan masalah?; (3) apakah kemampuan koneksi berpengaruh terhadap kemampuan pemecahan masalah?; (4) apakah kemampuan pemahaman konsep berpengaruh terhadap kemampuan komunikasi?; (5) apakah kemampuan pemahaman konsep berpengaruh terhadap kemampuan koneksi?; (6) apakah kemampuan komunikasi berpengaruh terhadap kemampuan koneksi?; (7) apakah kemampuan pemahaman konsep berpengaruh tidak langsung terhadap kemampuan pemecahan melalui 
kemampuan komunikasi?; (8) apakah kemampuan pemahaman konsep berpengaruh tidak langsung terhadap kemampuan pemecahan masalah melalui kemampuan koneksi? dan (9) apakah kemampuan komunikasi berpengaruh tidak langsung terhadap kemampuan pemecahan masalah melalui kemampuan koneksi?. Tujuan yang dicapai dari penelitian, yaitu untuk mengetahui dan menganalisis (1) pengaruh kemampuan pemahaman konsep terhadap kemampuan pemecahan masalah; (2) pengaruh kemampuan komunikasi terhadap kemampuan pemecahan masalah; (3) pengaruh kemampuan koneksi terhadap kemampuan pemecahan masalah; (4) pengaruh kemampuan pemahaman konsep terhadap kemampuan komunikasi; (5) pengaruh kemampuan pemahaman konsep terhadap kemampuan koneksi; (6) pengaruh kemampuan komunikasi terhadap kemampuan koneksi; (7) pengaruh tidak langsung kemampuan pemahaman konsep terhadap kemampuan pemecahan melalui kemampuan komunikasi; (8) pengaruh tidak langsung kemampuan pemahaman konsep terhadap kemampuan pemecahan masalah melalui kemampuan koneksi dan (9) pengaruh tidak langsung kemampuan komunikasi terhadap kemampuan pemecahan masalah melalui kemampuan koneksi.

\section{METODE PENELITIAN}

Jenis penelitian ini bersifat deskriptif dengan pendekatan kuantitatif. Metode yang digunakan adalah metode survei. Populasi dalam penelitian adalah seluruh siswa Kelas VII, VIII dan IX SMPN 1 Padang Jaya. Penentuan sampel penelitian menggunakan metode non-probability sampling, sehingga sampel dalam penelitian ini adalah seluruh siswa Kelas VII di sekolah tersebut yang berjumlah 122 orang yang terdiri atas 60 orang siswa laki dan 62 siswa perempuan. Variabel independen terdiri atas kemampuan pemahaman konsep $\left(\mathrm{X}_{1}\right)$, kemampuan komunikasi $\left(\mathrm{X}_{2}\right)$ dan kemampuan koneksi matematika $\left(\mathrm{X}_{3}\right)$. Variabel dependennya, yaitu kemampuan pemecahan masalah (Y).

\section{HASIL PENELITIAN DAN PEMBAHASAN}

Hasil penelitian mengenai pengaruh kemampuan pemahaman konsep, kemampuan komunikasi dan koneksi terhadap kemampuan pemecahan masalah pada siswa Kelas VII SMPN 1 Padang Jaya diuraikan sebagai berikut: 
Deskriptif statistik keempat variabel dalam penelitian ini dapat dilihat pada Tabel 1 .

\section{Tabel 1. Deskriptif Statistik Variabel Penelitian Statistics Descriptive}

\begin{tabular}{|l|r|r|r|r|}
\hline & $\begin{array}{c}\text { Kemampuan } \\
\text { Pemahaman } \\
\text { Konsep }\end{array}$ & $\begin{array}{c}\text { Kemampuan } \\
\text { Komunikasi }\end{array}$ & $\begin{array}{c}\text { Kemampuan } \\
\text { Koneksi }\end{array}$ & $\begin{array}{c}\text { Kemampuan } \\
\text { Pemecahan } \\
\text { Masalah }\end{array}$ \\
\hline Valid & 122 & 122 & 122 & 122 \\
Missing & 0 & 0 & 0 & 0 \\
Median & 41,5410 & 45,1721 & 34,4918 & 31,4754 \\
Mode & 41,5000 & 45,0000 & 35,0000 & 31,0000 \\
Std. Deviation & 38,00 & 43,00 & 35,00 & 31,00 \\
Variance & 5,02744 & 6,05033 & 5,58369 & 5,71096 \\
Range & 25,275 & 36,606 & 31,178 & 32,615 \\
Minimum & 23,00 & 26,00 & 26,00 & 23,00 \\
Maximum & 29,00 & 33,00 & 20,00 & 20,00 \\
Sum & 52,00 & 59,00 & 46,00 & 43,00 \\
\end{tabular}

Berdasarkan hasil penelitian statistik terhadap skor kemampuan pemahaman konsep siswa SMP Negeri 1 Padang Jaya diperoleh skor terendah 29 dan skor tertinggi 52 dengan rentang 21. Total skor tersebut diperoleh dari 12 butir pertanyaan. Jumlah skor teoritik minimal dan maksimal yang mungkin terjadi adalah 12 dan 60. Sebaran skor kemampuan pemahaman konsep kemampuan pemahaman konsep siswa sekolah ini dalam bentuk distribusi frekuensi skor dapat dilihat pada Tabel 2 .

Tabel 2. Distribusi Frekuensi Skor Kemampuan Pemahaman Konsep Siswa SMPN 1 Padang Jaya $\left(X_{1}\right)$

\begin{tabular}{|c|c|c|c|c|}
\hline No & $\begin{array}{c}\text { Interval Skor } \\
\text { Kemampuan } \\
\text { Pemahaman Konsep }\end{array}$ & $\begin{array}{c}\text { Frekuensi } \\
\text { Absolut } \\
\text { (Orang) }\end{array}$ & $\begin{array}{c}\text { Frekuensi Relatif } \\
(\%)\end{array}$ & $\begin{array}{c}\text { Frekuensi } \\
\text { Kumulatif (\%) }\end{array}$ \\
\hline 1 & $29-31$ & 3 & 2,46 & 2,45 \\
\hline 2 & $32-34$ & 8 & 6,56 & 9,03 \\
\hline 3 & $35-37$ & 14 & 11,47 & 20,50 \\
\hline 4 & $38-40$ & 26 & 21,31 & 41,81 \\
\hline 5 & $41-43$ & 24 & 19,67 & 61,48 \\
\hline 6 & $44-46$ & 27 & 22,14 & 83,62 \\
\hline 7 & $47-49$ & 14 & 11,47 & 95,09 \\
\hline 8 & $50-52$ & 6 & 4,92 & 100,00 \\
\hline \hline & Jumlah & $\mathbf{1 2 2}$ & $\mathbf{1 0 0}$ & $\mathbf{1 0 0}$ \\
\hline
\end{tabular}


Berdasarkan hasil perhitungan pada Tabel 2 di atas, maka sebaran data kemampuan pemahaman konsep siswa SMPN 1 Padang Jaya dapat diklasifikasikan menjadi tinggi, sedang dan rendah yang dapat dilihat pada Tabel 3.

\section{Tabel 3. Klasifikasi Skor Kemampuan Pemahaman Konsep Siswa SMPN 1 Padang Jaya $\left(\mathrm{X}_{1}\right)$}

\begin{tabular}{|c|c|c|c|}
\hline Kategori & $\begin{array}{c}\text { Interval Skor Kemampuan } \\
\text { Pemahaman Konsep }\end{array}$ & $\begin{array}{c}\text { Jumlah } \\
\text { (Orang) }\end{array}$ & $\begin{array}{c}\text { Persentase } \\
(\boldsymbol{\%})\end{array}$ \\
\hline Rendah & $<37$ & 25 & 20,49 \\
\hline Sedang & 37 s.d 47 & 77 & 63,11 \\
\hline Tinggi & $>47$ & 20 & 16,39 \\
\hline \multicolumn{2}{|r}{} & $\mathbf{1 2 2}$ & $\mathbf{1 0 0}$ \\
\hline
\end{tabular}

Tabel 3 menunjukkan bahwa skor kemampuan pemahaman konsep siswa SMPN 1 Padang Jaya yang dominan terdapat pada kategori sedang, yaitu sebanyak 77 orang $(63,11 \%)$. Kategori rendah dan tinggi berturut-turut sebanyak 25 orang $(20,49 \%)$ dan 20 siswa $(16,39 \%)$.

Berdasarkan hasil penelitian statistik terhadap skor kemampuan komunikasi siswa SMPN 1 Padang Jaya diperoleh skor terendah 33 dan skor tertinggi 59 dengan rentang 26. Total skor tersebut diperoleh dari 12 butir pertanyaan. Jumlah skor teoritik minimal dan maksimal yang mungkin terjadi adalah 12 dan 60. Sebaran skor kemampuan komunikasi siswa sekolah ini dalam bentuk distribusi frekuensi skor disajikan dalam Tabel 4.

Tabel 4. Distribusi Frekuensi Skor Kemampuan Komunikasi Siswa SMPN 1 Padang Jaya $\left(\mathbf{X}_{2}\right)$

\begin{tabular}{|c|c|c|c|c|}
\hline No & $\begin{array}{c}\text { Interval Skor } \\
\text { Kemampuan } \\
\text { Pemahaman Konsep }\end{array}$ & $\begin{array}{c}\text { Frekuensi } \\
\text { Absolut } \\
\text { (Orang) }\end{array}$ & $\begin{array}{c}\text { Frekuensi } \\
\text { Relatif } \\
(\mathbf{\%})\end{array}$ & $\begin{array}{c}\text { Frekuensi } \\
\text { Kumulatif } \\
(\boldsymbol{\%})\end{array}$ \\
\hline 1 & $30-33$ & 1 & 0,82 & 0,82 \\
\hline 2 & $34-37$ & 14 & 11,48 & 12,30 \\
\hline 3 & $38-41$ & 23 & 18,85 & 31,15 \\
\hline 4 & $42-45$ & 27 & 22,13 & 53,28 \\
\hline 5 & $46-49$ & 23 & 18,85 & 72,13 \\
\hline 6 & $50-53$ & 25 & 20,50 & 92,63 \\
\hline 7 & $54-57$ & 7 & 5,74 & 98,37 \\
\hline 8 & $58-61$ & 2 & 1,63 & 100 \\
\hline \hline & Jumlah & $\mathbf{1 2 2}$ & $\mathbf{1 0 0}$ & $\mathbf{1 0 0}$ \\
\hline
\end{tabular}


Berdasarkan hasil perhitungan yang terdapat pada Tabel 4 di atas, maka sebaran data kemampuan komunikasi siswa SMPN 1 Padang Jaya dapat diklasifikasikan menjadi tinggi, sedang dan rendah yang dapat dilihat pada Tabel 5.

Tabel 5. Klasifikasi Skor Kemampuan Komunikasi Siswa SMPN 1 Padang Jaya $\left(\mathbf{X}_{2}\right)$

\begin{tabular}{|c|c|c|c|}
\hline Kategori & $\begin{array}{c}\text { Interval Skor Kemampuan } \\
\text { Pemahaman Konsep }\end{array}$ & $\begin{array}{c}\text { Jumlah } \\
\text { (Orang) }\end{array}$ & $\begin{array}{c}\text { Persentase } \\
(\mathbf{\%})\end{array}$ \\
\hline \hline Rendah & $<39$ & 18 & 14,75 \\
\hline Sedang & 39 s.d 51 & 81 & 66,40 \\
\hline Tinggi & $>51$ & 23 & 18,85 \\
\hline \multicolumn{2}{|c|}{} & $\mathbf{1 2 2}$ & $\mathbf{1 0 0}$ \\
\hline
\end{tabular}

Tabel 5 menunjukkan bahwa skor kemampuan komunikasi siswa SMPN 1 Padang Jaya yang dominan terdapat pada kategori sedang sebanyak 81 orang $(66,40 \%)$. Kategori rendah dan tinggi berturut-turut sebanyak 18 orang $(14,75 \%)$ dan 23 orang $(18,85 \%)$.

Berdasarkan hasil penelitian statistik terhadap skor kemampuan koneksi siswa SMPN 1 Padang Jaya diperoleh skor terendah 20 dan skor tertinggi 46 dengan rentang 26. Total skor tersebut diperoleh dari 10 butir pertanyaan. Jumlah skor teoritik minimal dan maksimal yang mungkin terjadi adalah 10 dan 50. Sebaran skor kemampuan koneksi siswa sekolah ini dalam bentuk distribusi frekuensi skor disajikan dalam Tabel 6.

Tabel 6. Distribusi Frekuensi Skor Kemampuan Koneksi Siswa SMPN 1 Padang Jaya $\left(\mathrm{X}_{3}\right)$

\begin{tabular}{|c|c|c|c|c|}
\hline No & $\begin{array}{c}\text { Interval Skor } \\
\text { Kemampuan } \\
\text { Pemahaman Konsep }\end{array}$ & $\begin{array}{c}\text { Frekuensi } \\
\text { Absolut } \\
\text { (Orang) }\end{array}$ & $\begin{array}{c}\text { Frekuensi } \\
\text { Relatif } \\
(\boldsymbol{\%})\end{array}$ & $\begin{array}{c}\text { Frekuensi } \\
\text { Kumulatif } \\
(\boldsymbol{\%})\end{array}$ \\
\hline 1 & $17-20$ & 1 & 0,82 & 0,82 \\
\hline 2 & $21-24$ & 7 & 5,74 & 6,56 \\
\hline 3 & $25-28$ & 7 & 5,74 & 12,30 \\
\hline 4 & $29-32$ & 27 & 22,13 & 34,43 \\
\hline 5 & $33-36$ & 40 & 32,79 & 67,22 \\
\hline 6 & $37-40$ & 22 & 18,03 & 85,25 \\
\hline 7 & $41-44$ & 15 & 12,30 & 97,55 \\
\hline 8 & $45-48$ & 3 & 2,45 & 100,00 \\
\hline \hline & Jumlah & $\mathbf{1 2 2}$ & $\mathbf{1 0 0}$ & $\mathbf{1 0 0}$ \\
\hline
\end{tabular}


Berdasarkan hasil perhitungan yang terdapat pada Tabel 6 di atas, maka sebaran data kemampuan koneksi siswa SMPN 1 Padang Jaya dapat dikalsifikasikan menjadi tinggi, sedang dan rendah Tabel 7.

\section{Tabel 7. Klasifikasi Skor Kemampuan Koneksi Siswa SMPN 1 Padang Jaya $\left(\mathbf{X}_{3}\right)$}

\begin{tabular}{|c|c|c|c|}
\hline Kategori & $\begin{array}{c}\text { Interval Skor Kemampuan } \\
\text { Pemahaman Konsep }\end{array}$ & $\begin{array}{c}\text { Jumlah } \\
\text { (Orang) }\end{array}$ & $\begin{array}{c}\text { Persentase } \\
(\mathbf{\%})\end{array}$ \\
\hline Rendah & $<29$ & 15 & 12,29 \\
\hline Sedang & 29 s.d 40 & 89 & 72,95 \\
\hline Tinggi & $>40$ & 18 & 14,75 \\
\hline \multicolumn{2}{|r|}{ Jumlah } & $\mathbf{1 2 2}$ & $\mathbf{1 0 0}$ \\
\hline
\end{tabular}

Tabel 7 menunjukkan bahwa skor kemampuan koneksi siswa SMPN 1 Padang Jaya yang dominan terdapat pada kategori sedang sebanyak 89 orang $(72,95 \%)$. Kategori rendah dan tinggi berturut-turut sebanyak 15 orang $(12,29 \%)$ dan 18 orang $(14,75 \%)$.

Berdasarkan hasil penelitian statistik terhadap skor kemampuan pemecahan masalah siswa SMPN 1 Padang Jaya diperoleh skor terendah 20 dan skor tertinggi 43 dengan rentang 23. Total skor tersebut diperoleh dari 9 butir pertanyaan. Jumlah skor teoritik minimal dan maksimal yang mungkin terjadi adalah 9 dan 45. Sebaran skor kemampuan pemecahan masalah siswa sekolah ini bentuk distribusi frekuensi skor disajikan dalam Tabel 8.

Tabel 8. Distribusi Frekuensi Skor Kemampuan Pemecahan Masalah Siswa SMPN 1 Padang Jaya (Y)

\begin{tabular}{|c|c|c|c|c|}
\hline No & $\begin{array}{c}\text { Interval Skor } \\
\text { Kemampuan } \\
\text { Pemahaman Konsep }\end{array}$ & $\begin{array}{c}\text { Frekuensi } \\
\text { Absolut } \\
(\text { Orang) }\end{array}$ & $\begin{array}{c}\text { Frekuensi } \\
\text { Relatif } \\
(\boldsymbol{\%})\end{array}$ & $\begin{array}{c}\text { Frekuensi } \\
\text { Kumulatif } \\
(\boldsymbol{\%})\end{array}$ \\
\hline 1 & $20-22$ & 6 & 4,92 & 4,92 \\
\hline 2 & $23-25$ & 15 & 12,30 & 17,22 \\
\hline 3 & $26-28$ & 18 & 14,75 & 31,97 \\
\hline 4 & $29-31$ & 23 & 18,85 & 50,82 \\
\hline 5 & $32-34$ & 23 & 18,85 & 69,67 \\
\hline 6 & $35-37$ & 18 & 14,75 & 84,42 \\
\hline 7 & $38-40$ & 9 & 7,38 & 91,80 \\
\hline 8 & $41-43$ & 10 & 8,12 & 100 \\
\hline & Jumlah & $\mathbf{1 2 2}$ & $\mathbf{1 0 0}$ & $\mathbf{1 0 0}$ \\
\hline
\end{tabular}


Berdasarkan hasil perhitungan yang terdapat pada Tabel 8 di atas, maka sebaran data kemampuan pemecahan masalah siswa SMPN 1 Padang Jaya dapat dikalsifikasikan menjadi tinggi, sedang dan rendah yang dapat dilihat pada Tabel 9.

Tabel 9. Klasifikasi Skor Kemampuan Pemecahan Masalah Siswa SMPN 1 Padang Jaya (Y)

\begin{tabular}{|c|c|c|c|}
\hline Kategori & $\begin{array}{c}\text { Interval Skor Kemampuan } \\
\text { Pemahaman Konsep }\end{array}$ & $\begin{array}{l}\text { Jumlah } \\
\text { (Orang) }\end{array}$ & $\begin{array}{c}\text { Persentase } \\
(\%)\end{array}$ \\
\hline Rendah & $<26$ & 21 & 17,21 \\
\hline Sedang & 26 s.d 37 & 82 & 67,21 \\
\hline Tinggi & $>37$ & 19 & 15,57 \\
\hline \multicolumn{2}{|r|}{ Jumlah } & 122 & 100 \\
\hline
\end{tabular}

Tabel 9 menunjukkan bahwa skor kemampuan pemecahan masalah siswa SMPN 1 Padang Jaya yang dominan terdapat pada kategori sedang sebanyak 82 orang $(67,21 \%)$. Kategori rendah dan tinggi berturut-turut sebanyak 21 orang $(17,21 \%)$ dan 19 orang $(15,57 \%)$.

\section{Pengujian Persyaratan Analisis}

Pengujian persyaratan analisis yang dilakukan adalah menguji persyaratan normalitas variabel $\mathrm{X}_{1}, \mathrm{X}_{2}, \mathrm{X}_{3}$ dan $\mathrm{Y}$ yang diuraikan sebagai berikut:

\section{Hasil Uji Normalitas}

Pengujian normalitas data dilaksanakan dengan uji statistik Liliefors. Hasil uji normalitas keempat variabel penelitian sebagai berikut:

1. Hasil Uji Normalitas Variabel Kemampuan Pemahaman Konsep $\left(\mathrm{X}_{1}\right)$

$\left[F\left(Z_{i}\right)-S\left(Z_{i}\right)\right]$ yang disimbolkan dengan $L_{\text {hitung }}$ untuk diperoleh $L_{\text {hitung }}=0,116$ bila dibandingkan dengan nilai kritis pada $\mathrm{n}=122$ pada taraf signifikansi $\alpha=$ 0,05 adalah $\mathrm{L}_{\text {tabel }}=0,886$, maka $\mathrm{L}_{\text {hitung }}<\mathrm{L}_{\text {tabel }}$. Hasil ini menunjukkan bahwa variabel kemampuan pemahaman konsep terdistribusi normal.

2. Hasil Uji Normalitas Variabel Kemampuan Komunikasi $\left(\mathrm{X}_{2}\right)$

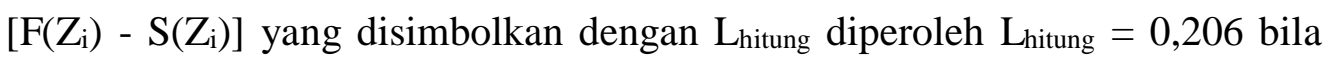
dibandingkan dengan nilai kritis pada $\mathrm{n}=122$ pada taraf signifikansi $\alpha=0,05$ adalah $\mathrm{L}_{\text {tabel }}=0,886$, maka $\mathrm{L}_{\text {hitung }}<\mathrm{L}_{\text {tabel. }}$. Hasil ini menunjukkan bahwa variabel kemampuan komunikasi terdistribusi normal. 
3. Hasil Uji Normalitas Variabel Koneksi Matematika $\left(\mathrm{X}_{3}\right)$

$[\mathrm{F}(\mathrm{Zi})-\mathrm{S}(\mathrm{Zi})]$ yang disimbolkan dengan $\mathrm{L}_{\text {hitung }}$ diperoleh $\mathrm{L}_{\mathrm{hitung}}=0,016$ bila dibandingkan dengan nilai kritis pada $\mathrm{n}=122$ pada taraf signifikansi $\alpha=0,05$ adalah $\mathrm{L}_{\text {tabel }}=0,886$, maka $\mathrm{L}_{\text {hitung }}<\mathrm{L}_{\text {tabel. }}$. Hasil ini menunjukkan bahwa variabel koneksi matematika terdistribusi normal.

4. Hasil Uji Normalitas Variabel Kemampuan Pemecahan Masalah (Y) $\left[\mathrm{F}\left(\mathrm{Z}_{\mathrm{i}}\right)-\mathrm{S}\left(\mathrm{Z}_{\mathrm{i}}\right)\right]$ yang disimbolkan dengan $\mathrm{L}_{\text {hitung }}$ untuk sebaran galat taksiran berdasarkan model regresi diperoleh $\mathrm{L}_{\text {hitung }}=0,023$ bila dibandingkan dengan nilai kritis pada $\mathrm{n}=122$ pada taraf signifikansi $\alpha=0,05$ adalah $\mathrm{L}_{\text {tabel }}=0,886$, maka $\mathrm{L}_{\text {hitung }}<\mathrm{L}_{\text {tabel. }}$. Hasil ini menunjukkan bahwa variabel kemampuan pemecahan masalah terdistribusi normal.

Rekapitulasi hasil uji normalitas seluruh variabel penelitian dapat dilihat pada Tabel 10.

Tabel 10. Hasil Uji Normalitas

\begin{tabular}{|c|c|c|c|c|}
\hline No & Variabel & Nilai $\mathbf{L}_{\text {hitung }}$ & $\begin{array}{c}\text { Pada } \mathbf{n}=\mathbf{1 2 2} \mathbf{L}_{\text {tabel }} \\
\boldsymbol{\alpha}=\mathbf{0 , 0 5}\end{array}$ & Keterangan \\
\hline \hline 1 & $\mathrm{X}_{1}$ & 0,116 & 0,886 & Terdistribusi normal \\
\hline 2 & $\mathrm{X}_{2}$ & 0,206 & 0,886 & Terdistribusi normal \\
\hline 3 & $\mathrm{X}_{3}$ & 0,016 & 0,886 & Terdistribusi normal \\
\hline 4 & $\mathrm{Y}$ & 0,023 & 0,886 & Terdistribusi normal \\
\hline
\end{tabular}

\section{Hasil Uji Linieritas}

Uji linieritas bertujuan untuk membuktikan bahwa masing-masing variabel eksogen mempunyai hubungan yang linier dengan variabel endogen yang hasilnya dapat dilihat pada Tabel 11.

Tabel 11. Hasil Uji Linieritas Regresi

\begin{tabular}{|c|c|c|c|c|c|}
\hline Pasangan Uji & Uji F & Signifikansi & Alpha & Kondisi & Keterangan \\
\hline \hline $\mathrm{X}_{2}$ atas $\mathrm{X}_{1}$ & 1,498 & 0,093 & 0,05 & Sig > Alpha & Linier \\
\hline $\mathrm{X}_{3}$ atas $\mathrm{X}_{1}$ & 0,714 & 0,815 & 0,05 & Sig > Alpha & Linier \\
\hline $\mathrm{Y}_{\text {atas }} \mathrm{X}_{1}$ & 0,518 & 0,960 & 0,05 & Sig > Alpha & Linier \\
\hline $\mathrm{X}_{3}$ atas $\mathrm{X}_{2}$ & 1,098 & 0,362 & 0,05 & Sig > Alpha & Linier \\
\hline $\mathrm{Y}$ atas $\mathrm{X}_{2}$ & 0,741 & 0,792 & 0,05 & Sig > Alpha & Linier \\
\hline $\mathrm{Y}$ atas $\mathrm{X} 3$ & 1,180 & 0,284 & 0,05 & Sig > Alpha & Linier \\
\hline
\end{tabular}

Tabel 11 menunjukkan bahwa nilai $\mathrm{F}_{\text {hitung }}$ deviation from linierity untuk pasangan uji variabel kemampuan komunikasi $\left(\mathrm{X}_{2}\right)$ atas kemampuan pemahaman 
konsep $\left(\mathrm{X}_{1}\right)$ sebesar 1,498 dengan nilai [ $\left.\operatorname{Sig}=0,093\right]>[\alpha=0,05]$. Berdasarkan hasil ini dapat disimpulkan bahwa distribusi pasangan uji variabel kemampuan pemecahan masalah atas variabel kemampuan pemahaman konsep $\left(\mathrm{X}_{1}\right)$ berpola linier. Nilai $F_{\text {hitung }}$ pada deviation from linierity untuk pasangan uji variabel kemampuan koneksi $\left(\mathrm{X}_{3}\right)$ atas kemampuan pemahaman konsep $\left(\mathrm{X}_{1}\right)$ sebesar 0,714 dengan nilai $[$ Sig $=0,815]>[\alpha=0,05]$. Berdasarkan hasil ini dapat disimpulkan bahwa distribusi pasangan uji variabel kemampuan koneksi $\left(\mathrm{X}_{3}\right)$ atas variabel kemampuan pemahaman konsep $\left(\mathrm{X}_{1}\right)$ berpola linier. Nilai $\mathrm{F}_{\text {hitung }}$ deviation from linierity untuk pasangan uji variabel kemampuan pemecahan masalah (Y) atas kemampuan pemahaman konsep $\left(\mathrm{X}_{1}\right)$ sebesar 0,518 dengan nilai $[$ Sig $=0,960]>[\alpha$ $=0,05]$. Berdasarkan hasil ini dapat disimpulkan bahwa distribusi pasangan uji variabel kemampuan pemecahan masalah (Y) atas variabel kemampuan pemahaman konsep $\left(\mathrm{X}_{1}\right)$ berpola linier.

Tabel 11 juga menunjukkan bahwa nilai $F_{\text {hitung }}$ deviation from linierity untuk pasangan uji variabel kemampuan koneksi (X3) atas kemampuan komunikasi $\left(\mathrm{X}_{2}\right)$ sebesar 1,098 dengan nilai [Sig $=0,362]>[\alpha=0,05]$. Berdasarkan hasil ini dapat disimpulkan bahwa distribusi pasangan uji variabel kemampuan koneksi $\left(\mathrm{X}_{3}\right)$ atas variabel kemampuan komunikasi $\left(\mathrm{X}_{2}\right)$ berpola linier. Nilai $\mathrm{F}_{\text {hitung }}$ deviation from linierity untuk pasangan uji variabel kemampuan pemecahan masalah (Y) atas kemampuan komunikasi $\left(\mathrm{X}_{2}\right)$ sebesar 0,741 dengan nilai [Sig $\left.=0,792\right]>[\alpha=0,05]$. Berdasarkan hasil ini dapat disimpulkan bahwa distribusi pasangan uji variabel kemampuan pemecahan masalah $(\mathrm{Y})$ atas variabel kemampuan komunikasi $\left(\mathrm{X}_{2}\right)$

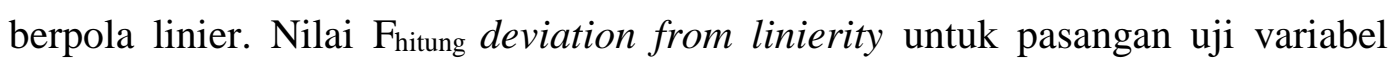
kemampuan pemecahan masalah $(\mathrm{Y})$ atas kemampuan koneksi $\left(\mathrm{X}_{3}\right)$ sebesar 1,180 dengan nilai $[$ Sig $=0,284]>[\alpha=0,05]$. Berdasarkan hasil ini dapat disimpulkan bahwa distribusi pasangan uji variabel kemampuan pemecahan masalah (Y) atas variabel kemampuan koneksi $\left(\mathrm{X}_{2}\right)$ berpola linier. 


\section{Hasil Analisis Korelasi Pearson}

Hasil analisis Korelasi Pearson antarvariabel dapat dilihat pada Tabel 12.

Tabel 12. Hasil Analisis Korelasi Pearson Correlations

\begin{tabular}{|c|c|c|c|c|c|}
\hline & & $\begin{array}{c}\text { Kemampuan } \\
\text { Pemahaman } \\
\text { Konsep }\end{array}$ & $\begin{array}{l}\text { Kemampuan } \\
\text { Komunikasi }\end{array}$ & $\begin{array}{l}\text { Kemampuan } \\
\text { Koneksi }\end{array}$ & $\begin{array}{c}\text { Kemampuan } \\
\text { Pemecahan } \\
\text { Masalah }\end{array}$ \\
\hline \multirow{3}{*}{$\begin{array}{l}\text { Kemampuan } \\
\text { Pemahaman } \\
\text { Konsep }\end{array}$} & $\begin{array}{l}\text { Pearson } \\
\text { Correlation }\end{array}$ & 1 & $.323^{* *}$ & $.422^{* *}$ & $.513^{* *}$ \\
\hline & Sig. (2-tailed) & & .000 & .000 & .000 \\
\hline & $\mathrm{N}$ & 122 & 122 & 122 & 122 \\
\hline \multirow[t]{3}{*}{$\begin{array}{l}\text { Kemampuan } \\
\text { Komunikasi }\end{array}$} & $\begin{array}{l}\text { Pearson } \\
\text { Correlation }\end{array}$ & & 1 & & \\
\hline & Sig. (2-tailed) & .000 & & .000 & .002 \\
\hline & $\mathrm{N}$ & 122 & 122 & 122 & 122 \\
\hline \multirow[t]{3}{*}{$\begin{array}{l}\text { Kemampuan } \\
\text { Koneksi }\end{array}$} & $\begin{array}{l}\text { Pearson } \\
\text { Correlation }\end{array}$ & & & 1 & \\
\hline & Sig. (2-tailed) & .000 & .000 & & .000 \\
\hline & $\mathrm{N}$ & 122 & 122 & 122 & 122 \\
\hline \multirow{3}{*}{$\begin{array}{l}\text { Kemampuan } \\
\text { Pemecahan } \\
\text { Masalah }\end{array}$} & $\begin{array}{l}\text { Pearson } \\
\text { Correlation }\end{array}$ & $.513^{* *}$ & $.277^{* *}$ & $.333^{* *}$ & 1 \\
\hline & Sig. (2-tailed) & .000 & .002 & .000 & \\
\hline & $\mathrm{N}$ & 122 & 122 & 122 & 122 \\
\hline
\end{tabular}

**. Correlation is significant at the 0.01 level (2-tailed).

Tabel 12 menunjukkan bahwa koefisien korelasi antara kemampuan pemahaman konsep dan kemampuan komunikasi sebesar 0,323 dengan thitung sebesar 3,739 lebih besar dari $t_{\text {table }}$ 1,9799. Hasil ini menunjukkan bahwa kemampuan pemahaman konsep dan kemampuan komunikasi berhubungan cukup kuat. Koefisien korelasi antara kemampuan pemahaman konsep dan kemampuan koneksi sebesar 0,422 dengan $t_{\text {hitung }}$ sebesar 5,102 lebih besar dari table 1,9799. Hasil ini menunjukkan bahwa kemampuan pemahaman konsep dan kemampuan koneksi berhubungan cukup kuat dan signifikan. Koefisien korelasi antara kemampuan pemahaman konsep dan kemampuan pemecahan masalah sebesar 0,513 dengan

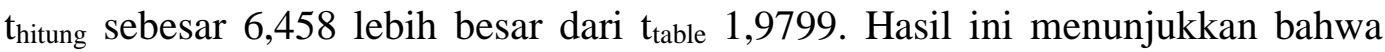
kemampuan pemahaman konsep dan kemampuan koneksi berhubungan cukup kuat dan signifikan.

Tabel 12 juga menunjukkan korelasi antara kemampuan komunikasi dan kemampuan koneksi sebesar 0,470 dengan $t_{\text {hitung }}$ sebesar 5,836 lebih besar dari $t_{\text {table }}$ 1,9799. Hasil ini menunjukkan bahwa kemampuan pemahaman konsep dan kemampuan koneksi berhubungan cukup kuat dan signifikan. Korelasi antara 
kemampuan komunikasi dan kemampuan pemecahan masalah sebesar 0,277 dengan thitung sebesar 2,910 lebih besar dari table 1,9799. Hasil ini menunjukkan bahwa kemampuan pemahaman konsep dan kemampuan koneksi berhubungan cukup kuat dan signifikan. Korelasi antara kemampuan koneksi dan kemampuan pemecahan masalah sebesar 0,333 dengan $t_{\text {hitung }}$ sebesar 3,871 lebih besar dari $t_{\text {table }}$ 1,9799. Hasil ini menunjukkan bahwa kemampuan pemahaman konsep dan kemampuan koneksi berhubungan cukup kuat dan signifikan.

\section{Pengujian Hipotesis Substruktur 1}

Pengujian hipotesis substruktur 1, yaitu kemampuan pemahaman konsep $\left(\mathrm{X}_{1}\right)$, kemampuan komunikasi $\left(\mathrm{X}_{2}\right)$ dan kemampuan koneksi $\left(\mathrm{X}_{3}\right)$ berpengaruh langsung positif terhadap kemampuan pemecahan masalah (Y). Hasil perhitungan diperoleh $F_{\text {hitung }}=21,352$ dengan nilai probabilitas $($ Sig. $)=0,000$. Oleh karena $[$ Sig $=.000]<\alpha=0,05]$, maka hasil ini menunjukkan bahwa kemampuan pemahaman konsep $\left(\mathrm{X}_{1}\right)$, kemampuan komunikasi $\left(\mathrm{X}_{2}\right)$ dan kemampuan koneksi $\left(\mathrm{X}_{3}\right)$ secara bersama-sama maupun individu berpengaruh langsung positif terhadap kemampuan pemecahan masalah dinyatakan teruji. Koefisien jalur $\left(\mathrm{X}_{1}\right)$ terhadap $(\mathrm{Y})=0,374$ dengan nilai $\mathrm{t}_{\text {hitung }}=4,474$ yang lebih besar dari $\mathrm{t}_{\text {kritis }}=1,960$ dan $\mathrm{Sig}$ $=0,000$. Koefisien jalur $\left(\mathrm{X}_{2}\right)$ terhadap $(\mathrm{Y})=0,181$ dengan $\mathrm{t}_{\text {hitung }}=2,169$, yang lebih besar dari $\mathrm{t}_{\text {kritis }}=1,960$ dan $\operatorname{Sig}=0,032$. Koefisien jalur $\left(\mathrm{X}_{3}\right)$ terhadap $(\mathrm{Y})$ sebesar 0,201 dengan nilai $t_{\text {hitung }}=2,251$ lebih besar dari $t_{\text {kritis }}=1,960$ dengan $\operatorname{Sig}=0,026$. Seluruh koefisien $\varepsilon$ dihitung berdasarkan model output model summary, yaitu $\varepsilon=$ $\sqrt{1-R^{2}}=\sqrt{1-0,352}=0,804$. Berdasarkan koefisien jalur tersebut, maka persamaan jalurnya dapat dibuat sebagai berikut:

$$
\begin{aligned}
\mathrm{Y} & =\rho \mathrm{yx}_{1} \mathrm{X}_{1}+\rho \mathrm{yx}_{2} \mathrm{X}_{2}+\rho \mathrm{yx}_{3} \mathrm{X}_{3}+\varepsilon \\
& =0,374 \mathrm{X}_{1}+0,181 \mathrm{X}_{2}+0,201 \mathrm{X}_{3}+0,804
\end{aligned}
$$

Besarnya pengaruh bersama-sama variabel $\left(\mathrm{X}_{1}, \mathrm{X}_{2}\right.$ dan $\left.\mathrm{X}_{3}\right)$ terhadap variabel $(\mathrm{Y})$ dilihat dari koefisien determinasi $\mathrm{R}_{\text {square }}=0,352$ atau $35,2 \%$ dan besarnya pengaruh variabel lain adalah $(\sqrt{1-0,307})^{2}=0,805$ atau sebesar $80,4 \%$.

Rekapitulasi hasil koefisien jalur pada pengujian hipotesis substruktur 1 di atas dapat dilihat pada Tabel 13. 
Tabel 13. Rekapitulasi Hasil Koefisien Jalur Hipotesis Substruktur 1

\begin{tabular}{|c|c|c|c|c|c|c|c|}
\hline $\begin{array}{c}\text { Pengaruh } \\
\text { Antar } \\
\text { variabel }\end{array}$ & $\begin{array}{c}\text { Koefisien } \\
\text { Jalur }\end{array}$ & $\begin{array}{l}\text { Nilai t } \\
\text { hitung }\end{array}$ & Sig & Nilai $\mathbf{F}$ & $\begin{array}{c}\text { Hasil } \\
\text { Pengujian }\end{array}$ & $\begin{array}{c}\text { Koefisien } \\
\text { Determinasi }\end{array}$ & $\begin{array}{c}\text { Koefisien } \\
\text { Variabel } \\
\text { Lain (sisa) }\end{array}$ \\
\hline $\mathrm{X}_{1}$ terhadap $\mathrm{Y}$ & 0,374 & 4,474 & 0,000 & \multirow{3}{*}{21,352} & $\mathrm{H}_{0}$ ditolak & \multirow{3}{*}{0,307} & \multirow{3}{*}{0,804} \\
\hline $\mathrm{X}_{2}$ terhadap $\mathrm{Y}$ & 0,181 & 2,169 & 0,032 & & $\mathrm{H}_{0}$ ditolak & & \\
\hline $\mathrm{X}_{3}$ terhadap $\mathrm{Y}$ & 0,201 & 2.251 & 0,026 & & $\mathrm{H}_{0}$ ditolak & & \\
\hline
\end{tabular}

Hubungan empiris antar variabel penelitian untuk substruktur 1 dapat dilihat pada Gambar 1.

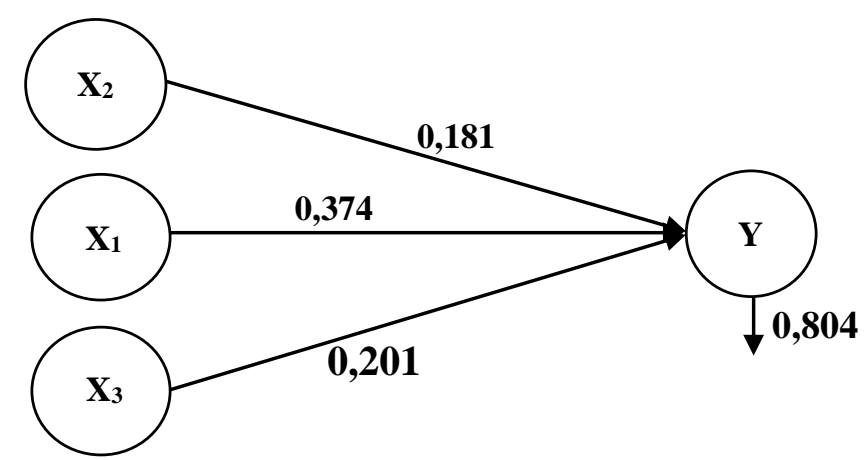

Gambar 1. Hubungan Kausal Empiris Substruktur 1

\section{Pengujian Hipotesis Substruktur 2}

Pengujian hipotesis substruktur 2, yaitu kemampuan pemahaman konsep $\left(\mathrm{X}_{1}\right)$ berpengaruh langsung positif terhadap kemampuan komunikasi $\left(\mathrm{X}_{2}\right)$. Hasil perhitungan diperoleh $\mathrm{F}_{\text {hitung }}=13,973$ dengan nilai probabilitas $($ Sig. $)=0,000$. Oleh karena $[$ Sig $=0,000<\alpha=0,05]$, maka hasil ini menunjukkan bahwa kemampuan pemahaman konsep $\left(\mathrm{X}_{1}\right)$ berpengaruh langsung positif terhadap kemampuan koneksi $\left(\mathrm{X}_{2}\right)$. Koefisien jalur $\left(\mathrm{X}_{1}\right)$ terhadap $\left(\mathrm{X}_{2}\right)$ sebesar 0,323 dengan $\mathrm{t}_{\text {hitung }}=3,738$ lebih besar dari $\mathrm{t}_{\text {kritis }}=1,960$ dan Sig $=0,000$.

Seluruh koefisien $\varepsilon$ dihitung berdasarkan model output model summary, yaitu $\varepsilon=\sqrt{1-R^{2}}=\sqrt{1-0,104}=0,946$. Berdasarkan koefisien jalur tersebut, maka persamaan jalurnya dapat dibuat, yaitu $X_{2}=0,323 X_{1}+0,946$.

Besarnya pengaruh bersama-sama variabel $\left(X_{1}, X_{2}\right.$ dan $\left.X_{3}\right)$ terhadap variabel $(\mathrm{Y})$ dilihat dari koefisien determinasi $\mathrm{R}_{\text {square }}=0,104$ atau $10,4 \%$ dan besarnya pengaruh variabel lain adalah $(\sqrt{1-0,104})^{2}=0,946$ atau sebesar 94,6\% .

Rekapitulasi hasil koefisien jalur pada pengujian hipotesis substruktur 2 di atas dapat dilihat pada Tabel 14. 
Pengaruh Kemampuan Pemahaman Konsep, Kemampuan Komunikasi Dan Koneksi Terhadap Kemampuan Pemecahan Masalah

Tabel 14. Rekapitulasi Hasil Koefisien Jalur Hipotesis Substruktur 2

\begin{tabular}{|c|c|c|c|c|c|c|c|}
\hline $\begin{array}{c}\text { Pengaruh } \\
\text { Antar variabel }\end{array}$ & $\begin{array}{c}\text { Koefisien } \\
\text { Jalur }\end{array}$ & $\begin{array}{c}\text { Nilai t } \\
\text { hitung }\end{array}$ & Sig & Nilai F & $\begin{array}{c}\text { Hasil } \\
\text { Pengujian }\end{array}$ & $\begin{array}{c}\text { Koefisien } \\
\text { Determinasi }\end{array}$ & $\begin{array}{c}\text { Koefisien } \\
\text { Variabel } \\
\text { Lain (sisa) }\end{array}$ \\
\hline $\mathrm{X}_{1}$ terhadap $\mathrm{X}_{2}$ & 0,323 & 3,738 & 0,000 & 13,973 & $\mathrm{H}_{0}$ ditolak & 0,104 & 0,946 \\
\hline
\end{tabular}

Hubungan empiris antar variabel penelitian untuk substruktur 2 dapat dilihat pada Gambar 2.

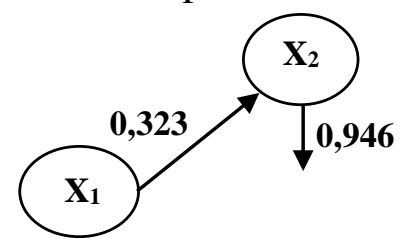

\section{Gambar 2. Hubungan Kausal Empiris Substruktur 2}

\section{Pengujian Hipotesis Substruktur 3}

Pengujian hipotesis substruktur 3, yaitu kemampuan pemahaman konsep $\left(\mathrm{X}_{1}\right)$ berpengaruh langsung positif terhadap kemampuan koneksi $\left(\mathrm{X}_{3}\right)$. Hasil perhitungan diperoleh $\mathrm{F}_{\text {hitung }}=26,051$ dengan nilai probabilitas $(\mathrm{Sig}$. $)=0,000$. Oleh karena [Sig $=0,000<\alpha=0,05]$, maka hasil ini menunjukkan bahwa kemampuan pemahaman konsep $\left(\mathrm{X}_{1}\right)$ berpengaruh langsung positif terhadap kemampuan koneksi $\left(\mathrm{X}_{3}\right)$. Koefisien jalur $\left(\mathrm{X}_{1}\right)$ terhadap $\left(\mathrm{X}_{3}\right)$ sebesar 0,442 dengan $\mathrm{t}_{\text {hitung }}=5,104$ lebih besar dari $\mathrm{t}_{\text {kritis }}=1,960$ dan Sig $=0,000$. Koefisien $\varepsilon$ dihitung berdasarkan model output model summary, yaitu $\varepsilon=\sqrt{1-R^{2}}=\sqrt{1-0,178}=0,939$. Berdasarkan koefisien jalur tersebut, maka persamaan jalurnya dapat dibuat, yaitu $\mathrm{X}_{3}=0,442 \mathrm{X}_{1}$ $+0,939$.

Besarnya pengaruh variabel $\mathrm{X}_{1}$ terhadap variabel $\mathrm{X}_{3}$ dilihat dari koefisien determinasi $\mathrm{R}_{\text {square }}=0,178$ atau $17,8 \%$ dan besarnya pengaruh variabel lain adalah $(\sqrt{1-0,178})^{2}=0,822$ atau sebesar $82,2 \%$.

Rekapitulasi hasil koefisien jalur pada pengujian hipotesis substruktur 3 di atas dapat dilihat pada Tabel 15.

Tabel 15. Rekapitulasi Hasil Koefisien Jalur Hipotesis Substruktur 3

\begin{tabular}{|c|c|c|c|c|c|c|c|}
\hline $\begin{array}{c}\text { Pengaruh } \\
\text { Antar variabel }\end{array}$ & $\begin{array}{c}\text { Koefisien } \\
\text { Jalur }\end{array}$ & $\begin{array}{c}\text { Nilai t } \\
\text { hitung }\end{array}$ & Sig & Nilai F & $\begin{array}{c}\text { Hasil } \\
\text { Pengujian }\end{array}$ & $\begin{array}{c}\text { Koefisien } \\
\text { Determinasi }\end{array}$ & $\begin{array}{c}\text { Koefisien } \\
\text { Variabel } \\
\text { Lain (sisa) }\end{array}$ \\
\hline $\mathrm{X}_{1}$ terhadap $\mathrm{X}_{3}$ & 0,442 & 5,104 & 0,000 & 26,051 & $\mathrm{H}_{0}$ ditolak & 0,178 & 0,822 \\
\hline
\end{tabular}


Hubungan empiris antar variabel penelitian untuk substruktur 3 dapat dilihat pada Gambar 3.

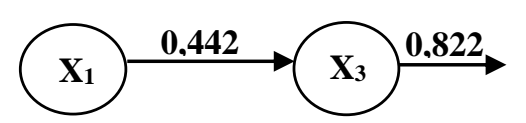

\section{Gambar 3. Hubungan Kausal Empiris Substruktur 3}

\section{Pengujian Hipotesis Substruktur 4}

Pengujian hipotesis substruktur 4, yaitu kemampuan komunikasi $\left(\mathrm{X}_{2}\right)$ berpengaruh langsung positif terhadap kemampuan koneksi $\left(\mathrm{X}_{3}\right)$. Hasil perhitungan diperoleh $\mathrm{F}_{\text {hitung }}=34,089$ dengan nilai probabilitas $(\mathrm{Sig}$. $)=0,000$. Oleh karena [Sig $=0,000<\alpha=0,05]$, maka hasil menunjukkan bahwa kemampuan komunikasi $\left(\mathrm{X}_{2}\right)$ berpengaruh langsung positif terhadap kemampuan koneksi $\left(\mathrm{X}_{3}\right)$ Koefisien jalur $\left(\mathrm{X}_{2}\right)$ terhadap $\left(\mathrm{X}_{3}\right)$ sebesar 0,470 dengan $\mathrm{t}_{\text {hitung }}=5,839$ lebih besar dari $\mathrm{t}_{\text {kritis }}=1,960$ dan Sig $=0,000$. Koefisien $\varepsilon$ dihitung berdasarkan model output model summary, yaitu $\varepsilon=\sqrt{1-R^{2}}=\sqrt{1-0,221}=0,883$. Berdasarkan koefisien jalur tersebut, maka persamaan jalurnya dapat dibuat, yaitu $X_{3}=0,470 X_{2}+0,883$.

Besarnya pengaruh variabel $\mathrm{X}_{2}$ terhadap variabel $\mathrm{X}^{3}$ dilihat dari koefisien determinasi $\mathrm{R}_{\text {square }}=0,221$ atau $22,1 \%$ dan besarnya pengaruh variabel lain adalah $(\sqrt{1-0,221})^{2}=0,883$ atau sebesar $88,3 \%$.

Rekapitulasi hasil koefisien jalur pada pengujian hipotesis substruktur 4 di atas dapat dilihat pada Tabel 16.

Tabel 16. Rekapitulasi Hasil Koefisien Jalur Hipotesis Substruktur 4

\begin{tabular}{|c|c|c|c|c|c|c|c|}
\hline $\begin{array}{c}\text { Pengaruh Antar } \\
\text { variabel }\end{array}$ & $\begin{array}{c}\text { Koefisien } \\
\text { Jalur }\end{array}$ & $\begin{array}{c}\text { Nilai t } \\
\text { hitung }\end{array}$ & Sig & $\begin{array}{c}\text { Nilai } \\
\mathbf{F}\end{array}$ & $\begin{array}{c}\text { Hasil } \\
\text { Pengujian }\end{array}$ & $\begin{array}{c}\text { Koefisien } \\
\text { Determinasi }\end{array}$ & $\begin{array}{c}\text { Koefisien } \\
\text { Variabel } \\
\text { Lain (sisa) }\end{array}$ \\
\hline $\mathrm{X}_{2}$ terhadap $\mathrm{X}_{3}$ & 0,470 & 5,839 & 0,000 & 34,089 & $\mathrm{H}_{0}$ ditolak & 0,221 & 0,779 \\
\hline
\end{tabular}

Hubungan empiris antar variabel penelitian untuk substruktur 4 dapat dilihat pada Gambar 4.

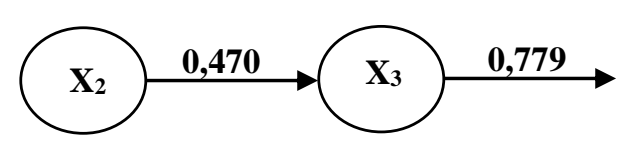

Gambar 4. Hubungan Kausal Empiris Substruktur 4 
Rangkuman koefisien jalur dapat dilihat pada diagram jalur pada Gambar 5.

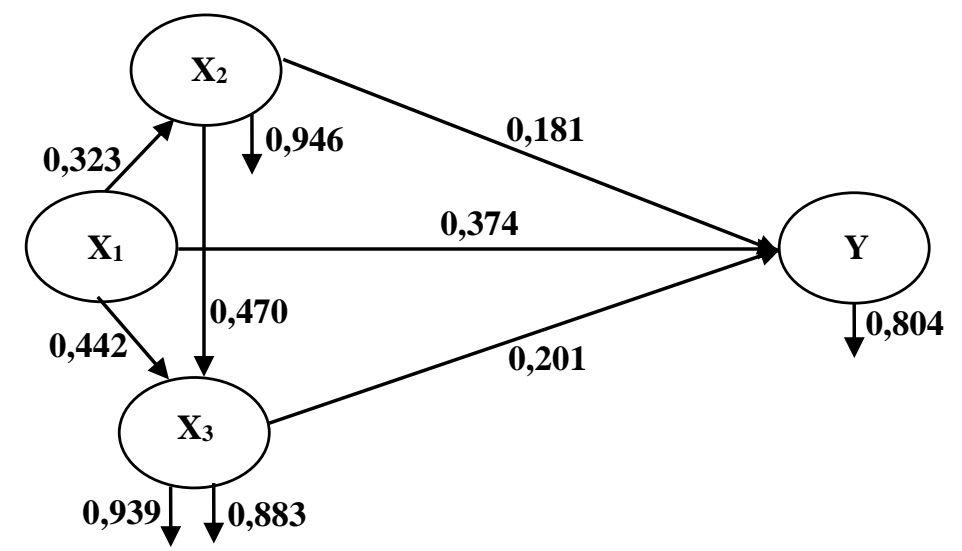

Gambar 5. Hubungan Kausal Empiris Antarvariabel Penelitian

\section{Pengujian Model}

Setelah dilakukan analisis, hasil perhitungan yang diperoleh digunakan untuk menguji model sebagai berikut:

\section{Pengujian Model Substruktur 1}

1. Kemampuan Pemahaman Konsep $\left(\mathrm{X}_{1}\right)$ Berpengaruh Langsung Positif terhadap Kemampuan Pemecahan Masalah (Y)

Berdasarkan hasil perhitungan koefisien jalur $\mathrm{X}_{1}=0,374$ dengan nilai $\mathrm{t}_{\text {hitung }}=$ 4,474 , sedangkan $t_{\text {tabel }}=1,960$ dan Sig $=0,000$ pada $\alpha=0,05$ dengan derajat kebebasan $(\mathrm{dk})=120$. Nilai $t_{\text {hitung }}=4,474$ lebih besar dari pada $t_{\text {tabel }}=1,960$ dan Sig $=0,000$ lebih kecil dari $\alpha=0,05$, maka koefisien jalur signifikan.

2. Kemampuan Komunikasi $\left(\mathrm{X}_{2}\right)$ Berpengaruh Langsung Positif terhadap Kemampuan Pemecahan Masalah (Y)

Berdasarkan hasil hasil perhitungan koefisien jalur $\mathrm{X}_{2}=0,181$ dengan nilai $t_{\text {hitung }}=2,169$, sedangkan $t_{\text {tabel }}=1,960$ dan Sig $=0,032$ pada $\alpha=0,05$ dengan derajat kebebasan $(\mathrm{dk})=120$. Nilai $t_{\text {hitung }}=2,169$ lebih besar dari pada $t_{\text {tabel }}=$ 1,960 dan Sig = 0,000 lebih kecil dari $\alpha=0,05$, maka koefisien jalur signifikan.

3. Kemampuan Koneksi $\left(\mathrm{X}_{3}\right)$ Berpengaruh Langsung Positif terhadap Kemampuan Pemecahan Masalah (Y)

Berdasarkan hasil perhitungan koefisien jalur $\mathrm{X}_{3}=0,201$ dengan nilai $\mathrm{t}_{\text {hitung }}=$ 2,251, sedangkan $t_{\text {tabel }}=1,960$ dan Sig $=0,026$ pada $\alpha=0,05$ dengan derajat 
kebebasan $(\mathrm{dk})=120$. Nilai $\mathrm{t}_{\text {hitung }}=2,251$ lebih besar dari pada $\mathrm{t}_{\text {tabel }}=1,960 \mathrm{dan}$ Sig $=0,000$ lebih kecil dari $\alpha=0,05$, maka koefisien jalur signifikan.

\section{Pengujian Model Substruktur 2}

Kemampuan Pemahaman Konsep $\left(\mathrm{X}_{1}\right)$ Berpengaruh Langsung Positif terhadap Kemampuan Komunikasi $\left(\mathrm{X}_{2}\right)$

Berdasarkan hasil hasil perhitungan koefisien jalur $\mathrm{X}_{1}=0,323$ dengan nilai $t_{\text {hitung }}=3,738$, sedangkan $t_{\text {tabel }}=1,960$ dan Sig $=0,000$ pada $\alpha=0,05$ dengan derajat kebebasan $(\mathrm{dk})=120$. Nilai $\mathrm{t}_{\text {hitung }}=5,839$ lebih besar dari pada $\mathrm{t}_{\text {tabel }}=1,960 \mathrm{dan} \mathrm{Sig}$ $=0,000$ lebih kecil dari $\alpha=0,05$, maka koefisien jalur signifikan.

\section{Pengujian Model Substruktur 3}

Kemampuan Pemahaman Konsep $\left(\mathrm{X}_{1}\right)$ Berpengaruh Langsung Positif terhadap Kemampuan Koneksi $\left(\mathrm{X}_{3}\right)$

Berdasarkan hasil hasil perhitungan hasil perhitungan koefisien jalur $\mathrm{X}_{1}=$ 0,422 dengan nilai $t_{\text {hitung }}=5,104$, sedangkan $t_{\text {tabel }}=1,960$ dan $\operatorname{Sig}=0,000$ pada $\alpha=$ 0,05 dengan derajat kebebasan $(\mathrm{dk})=120$. Nilai thitung $=5,104$ lebih besar dari pada $\mathrm{t}_{\text {tabel }}=1,960$ dan $\operatorname{Sig}=0,000$ lebih kecil dari $\alpha=0,05$, maka koefisien jalur signifikan.

\section{Pengujian Model Substruktur 4}

Kemampuan Komunikasi $\left(\mathrm{X}_{2}\right)$ Berpengaruh Langsung Positif terhadap Kemampuan Koneksi $\left(\mathrm{X}_{3}\right)$

Berdasarkan hasil perhitungan koefisien jalur diperoleh koefisien $\mathrm{X}_{2}=$ 0,470 dengan nilai $t_{\text {hitung }}=5,839$, sedangkan $t_{\text {tabel }}=1,960$ dan $\quad$ Sig $=0,000$ pada $\alpha=0,05$ dengan derajat kebebasan $(\mathrm{dk})=120$. Nilai $\mathrm{t}_{\text {hitung }}=5,839$ lebih besar dari pada $t_{\text {tabel }}=1,960$ dan $\operatorname{Sig}=0,000$ lebih kecil dari $\alpha=0,05$, maka koefisien jalur signifikan.

Secara lengkap, rekapitulasi hasil pengujian model dalam penelitian ini dapat dilihat pada Tabel 17. 
Tabel 17. Rekapitulasi Pengujian Hipotesis

\begin{tabular}{|c|c|c|c|c|c|}
\hline \multirow{2}{*}{ No } & \multirow{2}{*}{ Hipotesis } & \multirow{2}{*}{$\begin{array}{c}\text { Uji } \\
\text { Statistik }\end{array}$} & \multicolumn{2}{|c|}{ Uji t } & \multirow{2}{*}{ Kesimpulan } \\
\hline & & & thitung & $\mathbf{t}_{\text {tabel }}$ & \\
\hline 1 & $\begin{array}{l}\text { Kemampuan pemahaman konsep }\left(\mathrm{X}_{1}\right) \\
\text { berpengaruh langsung positif terhadap } \\
\text { kemampuan pemecahan masalah }(\mathrm{Y})\end{array}$ & $\begin{array}{l}\mathrm{H}_{\mathrm{a}}: \mathrm{X}_{1} \leq 0 \\
\mathrm{H}_{\mathrm{o}}: \mathrm{X}_{1}>0\end{array}$ & 4,474 & 1,960 & $\begin{array}{c}\text { Berpengaruh } \\
\text { langsung positif }\end{array}$ \\
\hline 2 & $\begin{array}{l}\text { Kemampuan komunikasi }\left(\mathrm{X}_{2}\right) \\
\text { berpengaruh langsung positif terhadap } \\
\text { kemampuan pemecahan masalah }(\mathrm{Y})\end{array}$ & $\begin{array}{l}\mathrm{H}_{\mathrm{a}}: \mathrm{X}_{1} \leq 0 \\
\mathrm{H}_{\mathrm{o}}: \mathrm{X}_{1}>0\end{array}$ & 2,169 & 1,960 & $\begin{array}{c}\text { Berpengaruh } \\
\text { langsung positif }\end{array}$ \\
\hline 3 & $\begin{array}{l}\text { Kemampuan koneksi }\left(\mathrm{X}_{3}\right) \text { berpengaruh } \\
\text { langsung positif terhadap kemampuan } \\
\text { pemecahan masalah }(\mathrm{Y})\end{array}$ & $\begin{array}{l}\mathrm{H}_{\mathrm{a}}: \mathrm{X}_{1} \leq 0 \\
\mathrm{H}_{\mathrm{o}}: \mathrm{X}_{1}>0\end{array}$ & 2,251 & 1,960 & $\begin{array}{c}\text { Berpengaruh } \\
\text { langsung positif }\end{array}$ \\
\hline 4 & $\begin{array}{l}\text { Kemampuan komunikasi }(\mathrm{X} 2) \\
\text { berpengaruh langsung positif terhadap } \\
\text { kemampuan koneksi }\left(\mathrm{X}_{3}\right)\end{array}$ & $\begin{array}{l}\mathrm{H}_{\mathrm{a}}: \mathrm{X}_{1} \leq 0 \\
\mathrm{H}_{\mathrm{o}}: \mathrm{X}_{1}>0\end{array}$ & 5,839 & 1,960 & $\begin{array}{c}\text { Berpengaruh } \\
\text { langsung positif }\end{array}$ \\
\hline 5 & $\begin{array}{l}\text { Kemampuan pemahaman konsep }\left(\mathrm{X}_{1}\right) \\
\text { berpengaruh langsung positif terhadap } \\
\text { kemampuan komunikasi }\left(\mathrm{X}_{2}\right)\end{array}$ & $\begin{array}{l}\mathrm{H}_{\mathrm{a}}: \mathrm{X}_{1} \leq 0 \\
\mathrm{H}_{\mathrm{o}}: \mathrm{X}_{1}>0\end{array}$ & 3,738 & 1,960 & $\begin{array}{c}\text { Berpengaruh } \\
\text { langsung positif }\end{array}$ \\
\hline 6 & $\begin{array}{l}\text { Kemampuan pemahaman konsep }\left(\mathrm{X}_{1}\right) \\
\text { berpengaruh langsung positif terhadap } \\
\text { kemampuan koneksi }\left(\mathrm{X}_{3}\right)\end{array}$ & $\begin{array}{l}\mathrm{H}_{\mathrm{a}}: \mathrm{X}_{1} \leq 0 \\
\mathrm{H}_{\mathrm{o}}: \mathrm{X}_{1}>0\end{array}$ & 5,104 & 1,960 & $\begin{array}{c}\text { Berpengaruh } \\
\text { langsung positif }\end{array}$ \\
\hline
\end{tabular}

\section{Pengaruh Langsung dan Tidak Langsung Antarvariabel}

Berdasarkan hasil perhitungan dan pengujian koefisien jalur pada Gambar 5 dapat ditaksirkan besar pengaruh langsung dan tidak langsung variabel independen dan variabel dependen, penentuan besar pengaruh langsung dan tidak langsung variabel independent dan variabel dependent dapat dilihat pada lampiran. Interprestasi pengaruh langsung dan tidak langsung variabel independen dan variabel dependen dapat dijelaskan pada Tabel 18.

Tabel 18. Besar Pengaruh Langsung dan tidak Langsung Antarvariabel

\begin{tabular}{|c|c|c|c|c|c|}
\hline \multirow{2}{*}{ Pengaruh } & \multicolumn{5}{|c|}{ Tubungan Kausal } \\
\cline { 2 - 5 } & \multirow{2}{*}{ Langsung } & \multicolumn{3}{|c|}{ Tidak Langsung } \\
\cline { 2 - 6 } & & $\begin{array}{c}\text { Melalui } \\
\mathbf{X}_{\mathbf{1}}\end{array}$ & $\begin{array}{c}\text { Melalui } \\
\mathbf{X}_{\mathbf{2}}\end{array}$ & $\begin{array}{c}\text { Melalui } \\
\mathbf{X}_{\mathbf{3}}\end{array}$ & Total \\
\hline $\mathrm{X}_{1}$ terhadap Y & 0,374 & - & $\begin{array}{c}0,374 \times 0,323 \times \\
0,181=0,022\end{array}$ & $\begin{array}{c}0,374 \times 0,442 \times \\
0,201=0,033\end{array}$ & $\begin{array}{c}0,374+0,022+0,033 \\
=0,429\end{array}$ \\
\hline $\mathrm{X}_{2}$ terhadap Y & 0,181 & - & - & $0,181 \times 0,470 \times$ \\
$0,201=0,017$ & $\begin{array}{c}0,181+0,017 \\
=0,20\end{array}$ \\
\hline $\mathrm{X}_{3}$ terhadap Y & 0,201 & - & - & - & 0,201 \\
\hline $\mathrm{X}_{1}$ dengan $\mathrm{X}_{2}$ & 0,323 & - & - & - & 0,323 \\
\hline $\mathrm{X}_{1}$ dengan $\mathrm{X}_{3}$ & 0,442 & - & - & - & 0,442 \\
\hline $\mathrm{X}_{2}$ terhadap $\mathrm{X}_{3}$ & 0,470 & - & - & - & 0,470 \\
\hline
\end{tabular}


Tabel 18 menunjukkan bahwa terdapat pengaruh langsung dan tidak langsusng antarvariabel. Kemampuan pemahaman konsep $\left(\mathrm{X}_{1}\right)$ berpengaruh langsung positif terhadap kemampuan pemecahan masalah (Y) sebesar 0,374; kemampuan komunikasi $\left(\mathrm{X}_{2}\right)$ juga berpengruh langsung terhadap kemampuan pemecahan masalah $(\mathrm{Y})$ sebesar 0,181. Kemampuan koneksi $\left(\mathrm{X}_{3}\right)$ berpengruh langsung terhadap kemampuan pemecahan masalah (Y) sebesar 0,201. Kemampuan pemahaman konsep $\left(\mathrm{X}_{1}\right)$ berpengaruh langsung positif terhadap kemampuan komunikasi $\left(\mathrm{X}_{2}\right)$ sebesar 0,323. Kemampuan pemahaman konsep $\left(\mathrm{X}_{1}\right)$ berpengaruh langsung positif terhadap kemampuan koneksi $\left(\mathrm{X}_{3}\right)$ sebesar 0,442; kemampuan komunikasi $\left(\mathrm{X}_{2}\right)$ kemampuan koneksi $\left(\mathrm{X}_{3}\right)$ sebesar 0,470.

Kemampuan pemahaman konsep $\left(\mathrm{X}_{1}\right)$ mempunyai pengaruh tidak langsung positif terhadap kemampuan pemecahan masalah (Y) melaui kemampuan komunikasi $\left(\mathrm{X}_{2}\right)$ sebesar 0,022 sedangkan melalui kemampuan koneksi $\left(\mathrm{X}_{3}\right)$ mempunyai pengaruh tidak langsung positif terhadap kemampuan pemecahan masalah (Y) sebesar 0,033. Pengaruh total kemampuan pemahaman konsep $\left(\mathrm{X}_{1}\right)$ terhadap kemampuan pemecahan masalah (Y) adalah sebesar 0,429. Kemampuan komunikasi $\left(\mathrm{X}_{2}\right)$ mempunyai pengaruh tidak langsung positif terhadap kemampuan pemecahan (Y) masalah melaui kemampuan koneksi $\left(\mathrm{X}_{3}\right)$ sebesar 0,017. Pengaruh total kemampuan komunikasi $\left(\mathrm{X}_{2}\right)$ terhadap kemampuan pemecahan masalah $(\mathrm{Y})$ sebesar 0,20 .

\section{Diagram Jalur Model Substruktur 1}

Pada diagram model substruktur 1 terlihat adanya pengaruh langsung kemampuan pemahaman konsep, kemampuan komunikasi dan kemampuan koneksi terhadap kemampuan pemecahan masalah.

1. Pengaruh Kemampuan Pemahaman Konsep terhadap Kemampuan Pemecahan Masalah

Kemampuan pemahaman konsep berpengaruh langsung positif terhadap kemampuan pemecahan masalah ditunjukkan koefisien jalur sebesar 0,374 dengan nilai $t_{\text {hitung }}=4,474$ yang lebih besar dari $t_{\text {kritis }}=1,960$ pada taraf nyata $\alpha$ $=0,05$. Artinya, kemampuan pemahaman konsep memiliki pengaruh langsung posiif terhadap kemampuan pemecahan masalah siswa SMPN 1 Padang Jaya. 
Hasil ini menunjukkan bahwa semakin tinggi kemampuan pemahaman konsep yang dimiliki oleh siswa, maka akan semakin tinggi pula keberhasilan dalam dalam memecahkan masalah. Hal ini dikarenakan dalam proses pemecahan masalah memberikan kesempatan kepada siswa untuk berperan aktif dalam mempelajari, mencari, dan menemukan sendiri informasi untuk diolah menjadi suatu konsep serta memahami dan menerapkan konsep itu kedalam berbagai situasi. Pemahaman konsep juga bermanfaat dalam meningkatkan ingatan, sehingga konsep yang telah diserap, dikuasai dan disimpan dalam jangka waktu yang lama dan dapat dipanggil kembali ketika diperlukan dalam memecahkan suatu masalah/soal.

2. Pengaruh Kemampuan Komunikasi terhadap Kemampuan Pemecahan Masalah Kemampuan komunikasi berpengaruh langsung positif terhadap kemampuan pemecahan masalah ditunjukkan koefisien jalur sebesar 0,181 dengan nilai thitung $=2,169$ yang lebih besar dari $t_{\text {kritis }}=1,960$ pada taraf nyata $\alpha$ $=0,05$. Artinya, kemampuan komunikasi memiliki pengaruh langsung positif terhadap kemampuan pemecahan masalah siswa SMPN 1 Padang Jaya. Hasil ini menunjukkan bahwa semakin tinggi kemampuan komunikasi yang dimiliki oleh siswa, maka semakin tinggi pula keberhasilan dalam dalam memecahkan masalah. Hal ini dikarenakan dalam pemecahan masalah diperlukan penyampaian ide-ide matematika, penjelasan konsep-konsep, penjelasan alogaritma dan cara unik untuk menyelesaikan masalah serta memberikan dugaan-dugaan berupa kata-kata, gambar, tabel, diagram ataupun persamaanpersamaan jika siswa dapat berkomunikasi, maka ia dapat merunutkan dan menjabarkan konstruksi solusi hasil analisis atau penjabaran logis dari permasalahan matematika (Hariwijaya dalam Nurul Fajri: 2012). Hulukati (2005) menyatakan bahwa kemampuan komunikasi matematis merupakan syarat untuk memecahkan masalah. Jika siswa tidak dapat berkomunikasi dengan baik memaknai permasalahan maupun konsep matematika, maka ia tidak dapat menyelesaikan masalah tersebut dengan baik. Dengan kemampuan komunikasi yang baik, maka suatu masalah akan lebih cepat bisa 
direpresentasikan dengan benar dan hal ini akan mendukung untuk penyelesaian masalah.

3. Pengaruh Kemampuan Koneksi terhadap Kemampuan Pemecahan Masalah

Kemampuan koneksi berpengaruh langsung positif terhadap kemampuan pemecahan masalah ditunjukkan koefisien jalur sebesar 0,201 dengan nilai thitung $=0,2251$ yang lebih besar dari $\mathrm{t}_{\text {kritis }}=1,960$ pada taraf $\alpha=0,05$. Artinya, kemampuan koneksi memiliki pengaruh langsung terhadap kemampuan pemecahan masalah siswa SMPN 1 Padang Jaya. Hasil ini menunjukkan bahwa semakin tinggi kemampuan koneksi matematika seseorang, maka akan semakin tinggi pula kemampuan pemecahan masalah.

Hal ini dikarenakan dalam pemecahan masalah diperlukan tidak hanya satu konsep saja, namun beberapa konsep, teori-teori dan dalil dalil yang saling berkaitan satu sama lainnya. Jika siswa dapat menghubungkan konsep-konsep dalam matematika maupun diluar matematika, maka menunjukkan kedalaman pemahaman siswa terhadap suatu materi matematika, seperti yang dinyatakan NCTM (2000), yaitu "When students can connect mathematical ideas, their undestanding is deeper and more lasting".

\section{Diagram Jalur Model Substruktur 2}

Pengaruh Kemampuan Pemahaman Konsep terhadap Kemampuan Komunikasi

Pada diagram model substruktur 2 terlihat adanya pengaruh langsung kemampuan pemahaman konsep terhadap kemampuan komunikasi. Kemampuan pemahaman konsep berpengaruh langsung terhadap kemampuan komunikasi ditunjukkan koefisien jalur sebesar 0,323 dengan nilai $t_{\text {hitung }}=3,738$ yang lebih besar dari $\mathrm{t}_{\text {kritis }}=1,960$ pada taraf $\alpha=0,05$. Artinya, kemampuan pemahaman konsep berpengaruh langsung terhadap kemampuan komunikasi siswa SMPN 1 Padang Jaya. Hasil ini menunjukkan bahwa semakin tinggi kemampuan pemahaman konsep matematika seseorang, maka akan semakin tinggi pula kemampuan komunikasi. Hal ini dikarenakan untuk berkomunikasi dengan baik, maka seseorang tentunya harus memiliki pemahaman yang dalam tentang apa yang akan dikomunikasikannya. 


\section{Diagram Jalur Model Substruktur 3}

Pengaruh Kemampuan Pemahaman Konsep terhadap Kemampuan Koneksi

Pada diagram model substruktur 3 terlihat adanya pengaruh langsung kemampuan pemahaman konsep terhadap kemampuan koneksi. Kemampuan pemahaman konsep berpengaruh langsung terhadap kemampuan koneksi ditunjukkan koefisien jalur sebesar 0,442 dengan nilai thitung $=5,104$ yang lebih besar dari $\mathrm{t}_{\text {kritis }}=1,960$ dengan pada taraf $\alpha=0,05$. Artinya, kemampuan pemahaman konsep memiliki pengaruh langsung terhadap kemampuan koneksi siswa SMPN 1 Padang Jaya. Hasil ini menunjukkan bahwa semakin tinggi kemampuan pemahaman konsep matematika seseorang, maka akan semakin tinggi pula kemampuan koneksi.

Hal ini dikarenakan konsep-konsep matematika tidak berdiri sendiri. Konsep-konsep dalam matematika memiliki struktur dan keterkaitan satu sama lainnya. Untuk mempelajari konsep matematika yang lebih tinggi diperlukan konsep-konsep yang telah dipelajari sebelumnya, sehingga konsep yang telah dipelajari harus diserap, dipahami, dikuasai dan disimpan untuk jangka waktu yang lama untuk dipanggil kembali ketika diperlukan. Oleh karena itu, seorang siswa perlu memiliki kemampuan pemahaman konsep untuk dapat mengetahui keterkaitan konsep yang diperlukan dalam memecahkan suatu masalah/soal.

\section{Diagram Jalur Model Substruktur 4}

Pengaruh Kemampuan Komunikasi terhadap Kemampuan Koneksi

Pada diagram model substruktur 4 terlihat adanya pengaruh langsung kemampuan komunikasi terhadap kemampuan koneksi. Kemampuan komunikasi berpengaruh langsung terhadap kemampuan koneksi ditunjukkan koefisien jalur sebesar 0,470 dengan nilai $t_{\text {hitung }}=5,839$ yang lebih besar dari $t_{\text {kritis }}=1,960$ pada taraf $\alpha=0,05$. Artinya, kemampuan komunikasi memiliki pengaruh langsung terhadap kemampuan koneksi siswa SMPN 1 Padang Jaya. Hasil ini menunjukkan bahwa semakin tinggi kemampuan komunikasi matematika seseorang, maka akan semakin tinggi pula kemampuan koneksi.

Hal ini dikarenakan kemampuan komunikasi yang baik maka siswa dapat berbagi ide dan memperjelas koneksi. Ruspiani (dalam Asni, 2013) menyatakan 
kemampuan koneksi matematika adalah "kemampuan siswa mengaitkan konsepkonsep baik antar konsep matematika itu sendiri (dalam matematika) maupun mengaitkan konsep matematika dengan bidang lainnya (luar matematika)". Menurut Saleh Haji (2012), "kemampuan komunikasi adalah kemampuan dalam menyampaikan ide-ide matematik baik secara lisan, tulisan maupun perbuatan".

\section{Path Diagram Hubungan Antarvariabel Penelitian}

Berdasarkan pengaruh antarvariabel penelitian terdapat pengaruh langsung (direct effect) dan pengaruh tidak langsung (indirect effect) sebagai berikut:

1. $\left(\mathrm{X}_{1} \rightarrow \mathrm{Y}\right)$, yaitu pengaruh langsung kemampuan pemahaman konsep terhadap kemampuan pemecahan masalah sebesar 0,374 . Artinya, ada pengaruh yang kuat antara variabel kemampuan pemahaman konsep dengan kemampuan pemecahan masalah.

2. $\left(\mathrm{X}_{2} \rightarrow \mathrm{Y}\right)$, yaitu pengaruh langsung kemampuan komunikasi terhadap kemampuan pemecahan masalah sebesar 0,181. Artinya, ada pengaruh yang sedang antara variabel kemampuan komunikasi dengan kemampuan pemecahan masalah.

3. $\left(\mathrm{X}_{3} \rightarrow \mathrm{Y}\right)$, yaitu pengaruh langsung kemampuan koneksi terhadap kemampuan pemecahan masalah sebesar 0,201. Artinya, ada pengaruh yang kuat antara variabel kemampuan koneksi dengan kemampuan pemecahan masalah.

4. $\left(\mathrm{X}_{1} \rightarrow \mathrm{X}_{2}\right)$, yaitu pengaruh langsung kemampuan pemahaman konsep dan kemampuan komunikasi sebesar 0,323. Artinya, ada pengaruh yang kuat antara variabel kemampuan pemahaman konsep dengan kemampuan komunikasi.

5. $\left(\mathrm{X}_{1} \rightarrow \mathrm{X}_{3}\right)$, yaitu pengaruh langsung antara kemampuan pemahaman konsep dan kemampuan koneksi sebesar 0,442. Artinya, ada pengaruh yang kuat antara variabel kemampuan pemahaman konsep dengan kemampuan koneksi.

6. $\left(\mathrm{X}_{2} \rightarrow \mathrm{X}_{3}\right)$, yaitu pengaruh langsung antara kemampuan komunikasi dan kemampuan koneksi sebesar 0,470. Artinya, ada pengaruh yang kuat antara variabel kemampuan pemahaman konsep dengan kemampuan komunikasi.

7. $\left(\mathrm{X}_{1} \rightarrow \mathrm{X}_{2} \rightarrow \mathrm{Y}\right)$, yaitu pengaruh tidak langsung kemampuan pemahaman konsep terhadap kemampuan pemecahan masalah melalui kemampuan komunikasi sebesar 0,022. Artinya, ada pengaruh yang lemah antara variabel kemampuan 
pemahaman konsep dengan kemampuan pemecahan masalah melalui kemampuan komunikasi.

8. $\left(\mathrm{X}_{1} \rightarrow \mathrm{X}_{3} \rightarrow \mathrm{Y}\right)$, yaitu pengaruh tidak langsung pemahaman konsep terhadap kemampuan pemecahan masalah melalui kemampuan koneksi sebesar 0,033. Artinya, ada pengaruh yang lemah antara variabel kemampuan pemahaman konsep dengan kemampuan pemecahan masalah melalui kemampuan koneksi.

9. $\left(\mathrm{X}_{2} \rightarrow \mathrm{X}_{3} \rightarrow \mathrm{Y}\right)$, yaitu pengaruh tidak langsung komunikasi terhadap kemampuan pemecahan masalah melalui kemampuan koneksi sebesar 0,017. Artinya, ada pengaruh yang lemah antara variabel kemampuan komunikasi dengan kemampuan pemecahan masalah melalui kemampuan koneksi.

Selain pengaruh langsung (direct effect) dan tidak langsung (indirect effect) di atas, ditemukan pula adanya pengaruh total (total effect) sebagai berikut:

1. $\left(\mathrm{X}_{1} \rightarrow \mathrm{Y}\right)$, yaitu pengaruh total kemampuan pemahaman konsep terhadap kemampuan pemecahan masalah sebesar 0,429. Artinya, ada pengaruh yang kuat antara variabel kemampuan pemahaman konsep dengan kemampuan pemecahan masalah.

2. $\left(\mathrm{X}_{2} \rightarrow \mathrm{Y}\right)$, yaitu pengaruh total kemampuan komunikasi terhadap kemampuan pemecahan masalah sebesar 0,20. Artinya, ada pengaruh yang kuat antara variabel kemampuan komunikasi dengan kemampuan pemecahan masalah.

\section{SIMPULAN}

Kemampuan pemahaman konsep memiliki pengaruh langsung positif terhadap kemampuan pemecahan masalah siswa SMPN 1 Padang Jaya. Simpulan ini memperkuat teori yang menyatakan semakin tinggi kemampuan pemahaman konsep yang dimiliki seorang siswa, maka akan semakin tinggi pula kemampuan memahami, menyelesaikan dan menafsirkan solusi suatu masalah. Hal ini berarti bahwa kemampuan pemecahan masalah dipengaruhi langsung positif oleh kemampuan pemahaman konsep. Dengan demikian, kemampuan pemahaman konsep yang tinggi akan berdampak positif kepada peningkatan kemmpuan pemecahan masalah.

Kemampuan komunikasi berpengaruh langsung terhadap kemampuan pemecahan masalah siswa SMPN 1 Padang Jaya. Simpulan ini memperkuat teori 
yang menyatakan semakin tinggi kemampuan komunikasi yang dimiliki seorang siswa, maka akan semakin tinggi pula kemampuan memahami, menyelesaikan dan menafsirkan solusi suatu masalah. Hal ini berarti bahwa kemampuan pemecahan masalah dipengaruhi langsung positif oleh kemampuan komunikasi. Dengan demikian, kemampuan komunikasi yang tinggi akan berdampak positif kepada peningkatan kemampuan pemecahan masalah.

Kemampuan koneksi berpengaruh langsung terhadap kemampuan pemecahan masalah siswa SMPN 1 Padang Jaya. Simpulan ini memperkuat teori yang menyatakan semakin tinggi kemampuan koneksi yang dimiliki seorang siswa, maka akan semakin tinggi pula kemampuan memahami, menyelesaikan dan menafsirkan solusi suatu masalah. Hal ini berarti bahwa kemampuan pemecahan masalah dipengaruhi langsung positif oleh kemampuan koneksi. Dengan demikian, kemampuan koneksi yang tinggi akan berdampak positif kepada peningkatan kemampuan pemecahan masalah.

Kemampuan pemahaman konsep berpengaruh terhadap kemampuan komunikasi siswa SMPN 1 Padang Jaya. Simpulan ini memperkuat teori yang menyatakan semakin tinggi kemampuan pemahaman konsep yang dimiliki seorang siswa, maka akan semakin tinggi pula kemampuan menghubungkan benda nyata, gambar, dan diagram kedalam ide matematika menjelaskan ide, situasi dan relasi matematik secara lisan atau tulisan dengan benda nyata, gambar, grafik dan aljabar, menyatakan peristiwa sehari hari dalam bahasa atau simbol matematis, menulis tentang matematika yang telah dipelajari. Hal ini berarti bahwa kemampuan komunikasi dipengaruhi langsung positif oleh kemampuan pemahaman konsep. Dengan demikian, kemampuan pemahaman konsep yang tinggi akan berdampak positif kepada peningkatan kemampuan komunikasi.

Kemampuan pemahaman konsep berpengaruh langsung terhadap kemampuan koneksi siswa SMPN 1 Padang Jaya. Simpulan ini memperkuat teori yang menyatakan semakin tinggi kemampuan pemahaman konsep yang dimiliki seorang siswa, maka akan semakin tinggi pula mengenali representasi ekuivalen dari konsep yang sama, menggunakan dan menilai keterkaitan antar topik matematika dan keterkaitan diluar matematika, menggunakan matematika dalam kehidupan sehari-hari. Kemampuan koneksi dipengaruhi langsung positif oleh 
kemampuan pemahaman konsep. Dengan demikian, kemampuan pemahaman konsep yang tinggi akan berdampak positif kepada peningkatan kemampuan koneksi.

Kemampuan komunikasi berpengaruh langsung terhadap kemampuan koneksi siswa SMPN 1 Padang Jaya. Simpulan ini memperkuat teori yang menyatakan semakin tinggi kemampuan komunikasi yang dimiliki seorang siswa, maka akan semakin tinggi pula mengenali representasi ekuivalen dari konsep yang sama, menggunakan dan menilai keterkaitan antar topik matematika dan keterkaitan di luar matematika, menggunakan matematika dalam kehidupan seharihari. Kemampuan koneksi dipengaruhi langsung positif oleh kemampuan komunikasi. Dengan demikian, kemampuan pemahaman konsep yang tinggi akan berdampak positif kepada peningkatan kemampuan koneksi.

Kemampuan pemahaman kosep berpengaruh tidak langsung terhadap kemampuan pemecahan masalah melalui kemampuan komunikasi siswa SMPN 1 Padang Jaya.

Kemampuan pemahaman kosep berpengaruh tidak langsung terhadap kemampuan pemecahan masalah melalui kemampuan koneksi siswa SMPN 1 Padang Jaya.

Kemampuan komunikasi berpengaruh tidak langsung terhadap kemampuan pemecahan masalah melalui kemampuan koneksi siswa SMPN 1 Padang Jaya.

\section{DAFTAR PUSTAKA}

Asni, Y. 2013. Pengaruh Pembelajaran Realistic Mathematic Education (RME) terhadap Peningkatkan Kemampuan Koneksi Matematika dan Kecemasan Belajar Matematika Siswa SMP Negeri 2 Talang Empat Bengkulu Tengah. Thesis: Universitas Bengkulu.

Baroody, A.J. 1993. Problem Solving, Reasoning, and Communicating, K-8 Helping Children Tink Mathematically. New York: Macmillan Publishing Company. Tersedia pada http://repository.upi.edu/3744/9/T PD 0908836 Bibliography.pdf. diakses pada tanggal 4 Mei 2015.

Baroody, A.J. 2012. Kemampuan Komunikasi Matematis Siswa. [Online]. Tersedia pada http://catatantanti.blogspot.com/2012/11/komunikasimatematika.html. Diakses pada tanggal 4 Mei 2015. 
Choto, A. 2009. Matematika Objek Dasar. Tersedia pada http://aanchoto.com/2009/09/matematika-objek-dasar/. Diakses pada tanggal 12 April 2015.

Dianne, A. 2003. Meningkatkan Kemampuan Koneksi Matematika Siswa Sekolah Lanjutan Tingkat Pertama dengan Menggunakan Metode Inkuiri. Program Pascasarjana (PPs) Universitas Pendidikan Indonesia. (Tesis tidak Dipublikasikan).

Eddy, I. 2012. Pengaruh Self-Efficacy, Kemampuan Pemahaman Konsep dan Kemampuan Berpikir Kreatif terhadap Kemampuan Pemecahan Masalah serta Dampaknya terhadap Hasil Belajar Matematika. Thesis: Universitas Bengkulu.

Fachrurazi. 2011. Penerapan Pembelajaran Berbasis Masalah untuk Meningkatkan Kemampuan Berpikir Kritis dan Komunikasi Matematis Siswa Sekolah Dasar. Jurnal Universitas Pendidikan Indonesia. Edisi Khusus. No.01.

Fajri, N. 2012. Korelasi Antara Kemampuan Koneksi dan Komunikasi Matematis Siswa dengan Menggunakan Pendekatan Contextual Teaching and Learning (CTL). Tersedia pada http://download.portalgaruda.org/article.php?=318217\&val=6356\&title= Korelasi\%20Antara\%20kemampuan\%20koneksi\%20dan\%20Komunikas i\%20matematis\%20Siswa\%20Dengan\%20Menggunakan\%20Pendekatan \%20Contextual\%20Teaching\%20And\%20Learrning (CTL). Diakses pada tanggal 4 Mei 2015.

Firmansyah. 2001. Komunikasi Matematika. Tersedia pada http://updatekerinci.blogspot.com/2001/12/komunikasi-matematik. Diakses pada tanggal 4 Juli 2015.

Haji, S. 2011. Meningkatkan Kemampuan Komunikasi Siswa melalui Pembelajaran Problem Posing. Makalah Disampaikan pada Seminar Nasional 2011. FKIP Universitas Bengkulu.

2012. Develoving Student Character Through Realistik Mathematics Learning. Proceeding $3^{\text {th }}$ International Seminar 2012: Building Indonesian Charactes through the Development of Early, Elementary, and Secondary Education: 310-317.

Hamid, F. 2010. Modul Riset Publication 3 SKS, Pokok Bahasan Paradigama Penelitian Kuantitatifdan Kualitatif. Universitas Muhammadiyah Bengkulu: Pusat Pengembangan Bahan Ajar.

Hariyadi, R. 2012. Definisi Pemahaman Konsep dalam Pembelajaran. Tersedia pada http://id.shovoong.com/social-sciences/education/226415. Diakses pada tanggal 15 April 2015.

Hepsi, N. 2012. Pembelajaran Metakognitif untuk Meningkatkan Pemahaman dan Koneksi Matematika Siswa SMU Ditinjau dari Perkembangan Kognitif Siswa: Studi Eksperimen pada Siswa Salah Satu SMU di Cirebon. Program Pascasarjana (PPs) Universitas Pendidikan Indonesia. (Tesis tidak Dipublikasikan).

Hulukati, E. 2005. Mengembangkan kemampuan Komunikasi dan pemecahan Masalah Matematika Siswa melalui Model Pemebelajaran Generatif. Tesis, Universitas Pendidikan Indonesia. Tersedia pada 
http://www.goole.com/\#q=hulukati+2005\%3A+kemampuan+komunikasi Diakses pada tanggal 30 April 2015.

Kartika, Y. 2004. Meningkatkan Kemampuan Koneksi Matematika Siswa dengan Pembelajaran Learning Cycle. Tersedia di http://file.upi.edu/Direktori/ FMIPA/JUR_PEND_MATEMATIKA/198207282005012-KARTIKA YULIANTI/makalah_LC_(Solo).pdf. Diakses pada tanggal 4 April 2015. Kusuma, D.A. 2008. Meningkatkan Kemampuan Koneksi Matematik dengan Menggunakan Pendekatan Konstruktivisme. Tersedia pada http://pustaka.unpad.ac.id/wp.content/uploads/2009/06/meningkatkanke mampuan-koneksi-matematik.pdf. Diakses pada tanggal 4 April 2015.

Lestari, K.E. 2013. Implementasi Brain-Based Learning untuk Meningkatkan Kemampuan Koneksi dan Kemampuan Berpikir Kritis Matematis Siswa Sekolah Menengah Pertama. Tesis SPS Universitas Pendidikan Indonesia. Mulyana, D. 2014. Rangkuman Buku Ilmu Komunikasi: Suatu Pengantar. Tersedia pada https://riesari.wordpress.com/2014/07/10/rangkuman-buku-ilmukomunikasi-suatu-pengantar-karya-dedy-mulyana/. Diakses pada tanggal 30 April 2015.

Nana, S. 2008. Metode Penelitian Pendidikan. Bandung: Remaja Rosda Karya.

NCTM. 2000. Principles and Standards for School Mathematics. America: Library of Congress Cataloguing.

Oemar, H. 2008. Kurikulum dan Pembelajaran. Jakarta: Bumi Aksara.

Prayitno, S. 2013. Kemampuan Komunikasi Siswa dalam Menyelesaikan Soal Matematika Berjenjang. Makalah Dipresentasikan dalam Seminar Nasional Jurusan Matematika, Fakultas Matematika dan Ilmu Pengetahuan Alam, Universitas Negeri Surabaya pada tanggal 18 Mei 2013.

Purwanto, S.E. 2010. Meningkatkan Kemampuan Pemacahan Masalah Siswa SMP dan MTs melalui Pembelajaran Matematika Realistik. Thesis. Universitas Pendidikan Indonesia.

Ridwan \& Kuncoro. 2006. Cara Menggunakan dan Memaknai Analisis Jalur (Path Analysis). Bandung: Alfabeta.

Rike. M. 2011. Pemahaman Konsep. Tersedia pada http://id.scribd.com/doc/67839324/Pemahaman-Konsep. Diakses pada tanggal 14 April 2015.

Sahat, S. 2007. Mengembangkan Kemampuan Berpikir Logis Dan Komunikasi Matematik Siswa Sekolah Menengah Pertama Melalui Pendekatan Matematika Realistik. Tersedia pada http://digilib.upi.edu/digitalview.php?digital_id=1474. Diakses pada tanggal 4 Mei 2015.

Schunk, D.H. 2012 Teori-Teori Pembelajaran: Perspektif Pendidikan. Edisi Keenam. Yogyakarta: Pustaka Pelajar.

Stefanus. 2011. Metode Penelitian dan Beberapa Filsafat Ilmu. Tersedia pada http://emboen.files.wordpress.com. Diakses pada tanggal 12 November 2015.

Sudjana. 1996. Metode Statistika. Bandung. Tarsito

Sugiyono. 2010. Metode Penelitian Kuantitatif, Kualitatif dan $R \&$ D. Bandung: Alfabeta. 
Suharsimi, A. 2004. Prosedur Penelitian: Suatu Pendekatan Praktek. Jakarta: Rineka Cipta.

Sumarmo. 2006. Pembelajaran Keterampilan Membaca Matematika pada siswa Sekolah Menengah. Bandung: Jurnal Fakultas Matematika dan Ilmu Pengetahuan Alam, Universitas Pendidikan Indonesia.

Sya'roni. 2010. Pengaruh Kemampuan Pemahaman Konsep, Penalaran dan Komunikasi terhadap Kemampuan Pemecahan Masalah Peserta Didik Kelas VIII pada Materi Pokok Pythagoras di SMP Nusa Bangsa Demak Tahun Pelajaran 2010/2011. Undergraduate (S1) Thesis, IAIN Walisongo.

Syaifudin, A. 2004. Metode Penelitian. Yogyakarta: Pustaka Pelajar. 2008. Realibilitas dan Validitas. Jakarta: Pustaka Pelajar.

Wahyu, H. 2013. Mengembangkan Keterampilan Kemampuan Komunikasi dan Berpikir Logis serta Disposisi Matematika Siswa SMA melalui Pembelajaran Berbasis Masalah. Prosiding Seminar Nasional, Universitas Pendidikan Indonesia.

Wardani, S. 2004. Penilaian Pembelajaran Matematika Berbasis Kompetensi. Diklat Instruktur/Pengembang Matematika SMK tanggal 7 s.d 20 Juli 2004 di Pusat Pengembangan dan Penataran Guru Matematika (PPPG) Matematika Yogyakarta. Yogyakarta: Departemen Pendidikan Nasional: Direktorat Jenderal Pendidikan Dasar dan Menengah, Pusat Pengembangan Pemberdayaan Pendidik dan Tenaga Kependidikan (PPPPTK) Matematika.

2010. Teknik Pengembangan Instrumen Penilaian Hasil Belajar Matematika di SMP/MTs, Diklat Guru Pemandu/Guru Inti/Pengembang Matematika SMP Jenjang Dasar Tahun 2010. Yogyakarta: Departemen Pendidikan Nasional, Direktorat Jenderal Pendidikan Dasar dan Menengah, Pusat Pengembangan Pemberdayaan Pendidik dan Tenaga Kependidikan (PPPPTK). 